\title{
Multi-level remodeling of transcriptional landscapes in aging and longevity
}

\author{
Rochelle W. Lai ${ }^{1, \#}$, Ryan Lu, ${ }^{1, \#}$, Prakroothi S. Danthi ${ }^{1}$, Juan I. Bravo ${ }^{1,2}$, Alexandre Goumba ${ }^{1}$, Nirmal Kumar \\ Sampathkumar ${ }^{1}$ E Bérénice A. Benayoun ${ }^{1,3,4, *}$ \\ ${ }^{1}$ Leonard Davis School of Gerontology, University of Southern California, Los Angeles, CA 90089, ${ }^{2}$ Graduate program in the Biology of \\ Aging, University of Southern California, Los Angeles, CA 90089, ${ }^{3}$ USC Norris Comprehensive Cancer Center, Epigenetics and Gene \\ Regulation, Los Angeles, CA 90089, ${ }^{4}$ USC Stem Cell Initiative, Los Angeles, CA 90089, USA
}

\begin{abstract}
In multi-cellular organisms, the control of gene expression is key not only for development, but also for adult cellular homeostasis, and gene expression has been observed to be deregulated with aging. In this review, we discuss the current knowledge on the transcriptional alterations that have been described to occur with age in metazoans. First, we discuss age-related transcriptional changes in protein-coding genes, the expected functional impact of such changes, and how known pro-longevity interventions impact these changes. Second, we discuss the changes and impact of emerging aspects of transcription in aging, including age-related changes in splicing, IncRNAs and circRNAs. Third, we discuss the changes and potential impact of transcription of transposable elements with aging. Fourth, we highlight small ncRNAs and their potential impact on the regulation of aging phenotypes. Understanding the aging transcriptome will be key to identify important regulatory targets, and ultimately slow-down or reverse aging and extend healthy lifespan in humans. [BMB Reports 2019; 52(1): 86-108]
\end{abstract}

\section{INTRODUCTION}

In multi-cellular organisms, the control of gene expression is key not only for development, but also for adult cellular homeostasis, and deregulation of gene expression correlates with aging (1-4). Aging is the main risk factor for many chronic diseases, such as neurodegeneration, cardiovascular disease, type II diabetes, osteoporosis, and cancer. Several conserved and interconnected pathways are deregulated during aging, delineating "hallmarks" or "pillars" of aging $(5,6)$. However,

${ }^{*}$ Corresponding author. Tel: +1-213-821-5997; E-mail: berenice. benayoun@usc.edu

${ }^{\text {"TThe }}$ These authors contributed equally to this work.

https://doi.org/10.5483/BMBRep.2019.52.1.296

Received 13 October 2018

Keywords: Aging, Longevity, ncRNA, Transcriptome how these hallmarks are achieved throughout the life of an organism is still poorly understood.

In the laboratory, several models are used to study aging: (i) chronological aging (i.e. the time that passed in the organism's life), which most closely corresponds to the most intuitive definition of aging, (ii) replicative aging (i.e. the number of times a cell can divide; most used to study aging in yeast) (7), (iii) cellular senescence, which corresponds to the replicative limit of cells before they enter irreversible cell cycle arrest, also dubbed the 'Hayflick limit' (8), and (iv) progeria or premature aging syndromes (i.e. Hutchinson-Gilford or Werner Syndrome) (9). Although aging is a common feature of many taxa, the rate of aging differs between species, and accumulating evidence suggests that the process can be fine-tuned within a species based on environmental cues, inter-individual genetic variations, and even sex (10). In this review, we will focus primarily on transcriptional landscape alterations in chronological aging and pro-longevity models.

\section{REMODELING OF THE PROTEIN CODING TRANSCRIPTIONAL LANDSCAPE WITH AGING AND IN LONGEVITY MODELS}

In this review, we chose to compare age-related and longevityrelated gene expression changes in different vertebrate species (e.g. mouse, human, rat, African turquoise killifish, etc.). Although this enabled us to draw more general comparisons, we understand that each species may have specific aging features, which limits our ability to draw a more general conclusion. Another general limitation in the field of aging genomics is the ill-defined age criteria for young and old animals that are profiled. For example, the age of "young" mice used in discussed studies ranges from age 1 to 4 months, while "old" mice range from age 18 to 30 months (Table 1). The lack of consensus age criteria makes reaching definitive conclusions on the effect of aging more difficult. Future studies should strive to use stricter age criteria for the study of aging, as well as include more time points along the life of animals to identify transcriptional trajectories with aging.

ISSN: 1976-670X (electronic edition)

Copyright (c) 2019 by the The Korean Society for Biochemistry and Molecular Biology

(ㄷ) This is an open-access article distributed under the terms of the Creative Commons Attribution Non-Commercial License (http://creativecommons.org/licenses/by-nc/4.0) which permits unrestricted non-commercial use, distribution, and reproduction in any medium, provided the original work is properly cited. 
Table 1. Aging signatures in vertebrate tissues

\begin{tabular}{|c|c|c|c|c|c|}
\hline Tissue & Upregulated pathways & Downregulated pathways & Species & Profiling method & Reference \\
\hline Liver & $\begin{array}{l}\text { Fibrosis } \\
\text { Immune Response } \\
\text { Inflammation } \\
\text { Lipid Metabolism } \\
\text { Protein Turnover } \\
\text { Stress Response }\end{array}$ & $\begin{array}{l}\text { Cell Cycle } \\
\text { DNA Replication } \\
\text { Drug Catabolic Processes } \\
\text { Metabolic Pathways } \\
\text { Oxidative Demethylation } \\
\text { Protein Synthesis } \\
\text { RNA Transport }\end{array}$ & $\begin{array}{l}\text { Mouse } \\
\text { Killifish } \\
\text { Rat }\end{array}$ & $\begin{array}{l}\text { Microarray } \\
\text { RNA-seq } \\
\text { RNA-seq } \\
\text { RNA-seq }\end{array}$ & $\begin{array}{l}(33,241) \\
(29,242,243) \\
\quad(244) \\
(238)\end{array}$ \\
\hline Heart & $\begin{array}{l}\text { Caspase Family } \\
\text { Chemokines } \\
\text { Immune Response } \\
\text { Lysosome } \\
\text { s100 Family }\end{array}$ & $\begin{array}{l}\text { Electron Transport Chain } \\
\text { Mitochondrion } \\
\text { TCA Cycle } \\
\text { Ubiquitin-dependent Catabolic Processes }\end{array}$ & $\begin{array}{l}\text { Human } \\
\text { Mouse }\end{array}$ & $\begin{array}{l}\text { RNA-seq } \\
\text { Microarray }\end{array}$ & $\begin{array}{l}(26) \\
(245)\end{array}$ \\
\hline Pancreatic Islets & $\begin{array}{l}\text { Extracellular Matrix } \\
\text { Global Methylation } \\
\text { Immune Response } \\
\text { Inflammatory Response } \\
\text { Oxidative Stress } \\
\text { Wound Healing }\end{array}$ & $\begin{array}{l}\text { Cell-cell Signaling } \\
\text { Metabolic Pathways } \\
\text { Neuron Recognition } \\
\text { Nutrient Sensing } \\
\text { Proliferation }\end{array}$ & $\begin{array}{l}\text { Rat } \\
\text { Mouse } \\
\text { Human }\end{array}$ & $\begin{array}{l}\text { Microarray } \\
\text { WGBS } \\
\text { scRNA-seq } \\
\text { RNA-seq } \\
\text { ChIP-seq } \\
\text { scRNA-seq }\end{array}$ & $\begin{array}{l}(25) \\
(246) \\
(247) \\
(49) \\
(50)\end{array}$ \\
\hline Brain & $\begin{array}{l}\text { Cerebellum } \\
\text { Complement System } \\
\text { Inflammatory Response } \\
\text { Stress Response }\end{array}$ & $\begin{array}{l}\text { Energy Metabolism } \\
\text { Growth/Trophic Factors } \\
\text { Inflammatory Response } \\
\text { Protein Synthesis }\end{array}$ & Mouse & Microarray & (24) \\
\hline & $\begin{array}{l}\text { Whole Brain } \\
\text { Apoptosis } \\
\text { Complement System } \\
\text { Immune Response } \\
\text { Inflammation } \\
\text { Lysosome } \\
\text { Ribosome } \\
\text { Stress Response }\end{array}$ & $\begin{array}{l}\text { Collagen } \\
\text { Metabolic Pathways } \\
\text { Mitochondrion } \\
\text { Protein Synthesis } \\
\text { Ribosomal Pathways } \\
\text { RNA Transport } \\
\text { Signal Transduction }\end{array}$ & $\begin{array}{l}\text { Killifish } \\
\text { Rat }\end{array}$ & $\begin{array}{l}\text { RNA-seq } \\
\text { RNA-seq }\end{array}$ & $\begin{array}{c}(248,244) \\
(238)\end{array}$ \\
\hline Kidney & $\begin{array}{l}\text { Extracellular Matrix } \\
\text { Immune Response } \\
\text { Ribosome }\end{array}$ & Stress Response & Human & Microarray & (28) \\
\hline
\end{tabular}

\section{Gene expression remodeling across cells and tissues in vertebrates}

Transcriptional remodeling aging signatures across tissues: We summarized reported age-related transcriptional changes across key tissues that are known to undergo age-related functional decline (i.e. liver, heart, pancreatic islets, brain, kidney) (Table 1). For simplicity and exhaustiveness' sake, both changes in gene expression from microarrays and RNA-sequencing datasets are reported. As illustrated in Table 1 , three common aging transcriptional signatures have been recurrently identified across different tissues and species. A prominent aging signature that affects all categories of tissues is increased expression of inflammatory pathways. More broadly, Gene Ontology (GO) categories of, 'immune response', 'stress response', 'chemokines', 'lysosome', 's100 family', 'caspase family', 'wound healing', 'fibrosis', and 'complement system' encompass genes that if left unattenuated, propagate an environment of oxidative stress and vascular damage (Table 1) (11-16). Importantly, chronic activation of the immune system is the defining characteristic of 'inflamm-aging' (i.e. a low-level, sterile, chronic state of inflammation with age), and the global increase of pro-inflammatory gene expression may thus be a driving factor in the development of age-related diseases (17-19). For example, the inappropriate activation of immune cells can exacerbate cancer progression (20), pathogenesis of type II diabetes (21), and cardiovascular disease susceptibility (22, 23).

Another notable general aging signature is an overall decrease in expression of metabolic genes (Table 1). Disrupted metabolic pathways in the mitochondrion (i.e. TCA cycle, electron transport chain), protein synthesis (i.e. cysteinyltRNA-synthase, phenylalanine-tRNA-synthase), and nutrient sensing (i.e. Cartpt, Npy, Ppy) were observed in the liver, heart, pancreatic islets, cerebellum, and whole brain tissues (24-26). The reduced efficiency and ability to process nutrients may limit nutrient availability and decreased xenobiotic 
metabolism may increase the event of drug toxicity in aging animals. Such a combination of metabolic decline may lay the foundation for the development of age-related diseases, such as cancer or Alzheimer's disease (27).

A common signature of decreased membrane integrity also seems to be a common theme in the liver, pancreatic islets, and kidney through the increase of 'fibrosis', 'extracellular matrix', and 'wound healing' gene expression (Table 1) (25, $28,29)$. The extracellular matrix is a lattice of polysaccharides and proteins that stem from the cell membrane, which provides structural support and scaffolding for physical communication between cells (30). In fibrosis and wound healing, the extracellular matrix expands and remodels to build upon or reestablish the cell barrier (30). However, an overgrowth of the extracellular matrix can hinder signaling between cells. This phenomenon is especially relevant for the liver, pancreatic islets, and kidney, as cells in these tissues heavily rely on membrane accessibility for metabolism, hormone release, and filtration. In the aging liver, the fibrotic extracellular matrix may contribute to the susceptibility to age-related diseases, since liver diseases involving inflammation, such as nonalcoholic fatty liver disease, are worsened with fibrosis (31). Concerning the pancreas, type II diabetes is a great model to understand the consequences of fibrotic islets, as fibrosis has been found to promote beta cell destruction, ultimately compromising the delivery of insulin (32). In the aging kidney, obstruction to the basement membrane may partially explain the age-related decline in glomerular filtration rate (28). Thus, the aging-associated loss in membrane integrity, predicted by the observed transcriptional remodeling, should be ultimately detrimental to the ability of cells to properly interact with the rest of the organism, and lead to functional decline.

Tissue-specific transcriptional remodeling with aging: Although common dysregulated pathways can be identified across tissues, many aging transcriptional defects seem to be tissue-specific (Table 1). For example, the aging liver presents a characteristic signature of decreased oxidative demethylation gene expression (33) (Table 1), a process that reverses the effects of regulatory or mutagenic methylation by removing methyl adducts from DNA and RNA (34). Deterioration of this ability to regulate and repair the methylome can induce improper gene expression. The pancreatic islets also reveal a unique aging signature of decreased 'cell-cell signaling', 'nutrient sensing', and 'neuronal recognition' gene expression (25). The decreased capacity to perform these functions creates juxtaposing outcomes. On one hand, decreased expression of these genes can create issues because the pancreatic islets depend on nearby cell communication, glucose sensing, and vagal nerve stimulation to assess energy status (35). Inaccurate sensing and transduction of energy status can harm the aging metabolism by disrupting the timing of pancreatic islet hormone release (35). Contrary to this, Riera et al. demonstrates an advantage with the decline of cell communication. Through the ablation of TRPV1 receptors and inhibition of calcitonin gene-related peptide, an insulin secretion blocker, the aging pancreas can improve its insulin release, yielding a more youthful metabolic profile (36). In light of these conflicting responses, pancreatic islet cell communication genes are evidently pleiotropic and are perhaps yet to be fully understood.

Table 2. Aging signatures in adult mouse stem cells

\begin{tabular}{|c|c|c|c|c|}
\hline Stem Cell & Upregulated pathways & Downregulated pathways & Profiling method & Reference \\
\hline Neural (SVZ) & $\begin{array}{l}\text { Cell Adhesion } \\
\text { Cell-cell Signaling } \\
\text { Cell Morphogenesis } \\
\text { Nerve Impulse Transmission } \\
\text { Neuron Differentiation }\end{array}$ & $\begin{array}{l}\text { Angiogenesis } \\
\text { Blood Vessel Development } \\
\text { Blood Vessel Morphogenesis } \\
\text { Development } \\
\text { Lysosomes } \\
\text { Regulation of Cell Motion } \\
\text { Response to Growth Factors } \\
\text { Vasculature }\end{array}$ & RNA-seq & $(38,39)$ \\
\hline Muscle (Satellite Cells) & $\begin{array}{l}\text { Apoptosis Regulation } \\
\text { Immune Response } \\
\text { Oxidation Reductin } \\
\text { Vascular Development }\end{array}$ & Histone Genes & Microarray & $(41,249)$ \\
\hline Hematopoietic & $\begin{array}{l}\text { Cell Adhesion } \\
\text { Cell Proliferation } \\
\text { Inflammation } \\
\text { Protein Aggregation } \\
\text { Repetitive Elements } \\
\text { Ribosome } \\
\text { Stress Response }\end{array}$ & $\begin{array}{l}\text { Cell Cycle } \\
\text { Epigenetic Regulation } \\
\text { Genomic Integrity }\end{array}$ & $\begin{array}{l}\text { Microarray } \\
\text { RNA-seq } \\
\text { scRNA-seq }\end{array}$ & $\begin{array}{l}(42) \\
(250) \\
(44)\end{array}$ \\
\hline
\end{tabular}


Age-related transcriptional remodeling: what about stem cells?: A hallmark of aging is the depletion and loss of function in adult stem cell pools (6). The ability of stem cells to preserve their quiescent state is central to maintaining a long-term functional stem cell pool for cell regeneration and tissue homeostasis. However, with aging, stem cell proliferation and the consequent rate of cell turnover have been observed to decline (37). The adult somatic stem cells that have been best studied at the genomic level during aging are: neural stem cells (NSCs), muscle stem cells or "satellite" cells (MuSCs), and hematopoietic stem cells (HSCs) (38-44) (Table 2). Interestingly, both HSCs and MuSCs display an upregulation of immune- related genes. This signature is akin to the one observed in bulk aging tissues (Table 1). Interestingly, a pro-inflammatory state resulting from an inappropriate immune response can both diminish and protect the viability and differentiation potential of the stem cell pool (45). This is also observed in NSCs and may be a product of an inflammatory microenvironment in the brain. In addition, aging HSCs and MuSCs share a transcriptional signature of decreased genome stability. For example, the decline in aging quiescent MuSCs may be explained by the silencing of genes through an increase in $\mathrm{H} 3 \mathrm{~K} 27 \mathrm{me} 3$ (40). A decrease in epigenetic regulators and cell cycle genes was also observed with age in HSCs $(43,44)$, which is accompanied by a loss in self-renewal and differentiation capability (43, 44). Aging NSCs and HSCs share an increased expression of genes involved in cell adhesion (39, 43), which may have consequences on migration capacity and survival. Specific to NSCs, decreased lysosomal gene expression was observed, which may explain a reduced ability of aged NSCs to transition out of the quiescent state and into the active stem cell pool (38).

Lessons from bulk vs. single cell transcriptome profiling: We have discussed both bulk microarray and RNA-sequencing (RNA-seq) datasets, as well as published emerging single-cell RNA sequencing (scRNA-seq) (Table 1, 2). Thus far, a major confounding factor of aging 'omics' studies (i.e. genome-wide analyses such as transcriptomics and epigenomics) lies in the heterogeneous cellular make-up of mammalian tissues, which makes it difficult to disentangle the significance of transcriptomic changes (i.e. resulting from changes in the underlying cellular makeup, or from cell type-autonomous changes). Computational deconvolution algorithms can be used to evaluate the relative contribution of cell type composition changes in transcriptomes of heterogeneous cell population (i.e. as is generally the case for tissues) (46), although they require reference purified transcriptional profiles of the cell types present in the mixture. In contrast, cell sorting may be used to analyze the fate of specific cell types. However, sorting relies on the existence of well-established cellular markers (which may not always be readily available for all cell types of interest or in emerging model organisms), and expression of such markers may itself be regulated with age, thus complicating data interpretation. Despite these limitations, bulk level RNA-seq is the more mature technology and enables the study of various aspects of transcription (e.g. strand-specificity, splicing isoforms, circRNAs, non-polyAdenylated RNAs, etc.).

In contrast to bulk methods, advances in single-cell profiling techniques now allow direct efficient and high-resolution transcriptional mapping of the transcriptomes of thousands of cells from heterogeneous samples by harnessing the power of microfluidics (e.g. Drop-seq, 10xGenomics Chromium, etc.) (47). These advances have enabled profiling at an unprecedented resolution in term of cell-to-cell variations and cell type identification (48). However, few studies have harnessed these single cell technologies in comparative aging transcriptomics studies yet. In a pioneering study of the aging pancreas at the single cell level, a transcriptional signature of loss of cell identity captured in scRNA-seq could not be detected in previous bulk RNA-seq studies $(49,50)$. However, it is important to note that most single-cell profiling technologies do not provide information on transcription beyond gene expression level, and they cannot robustly detect lowly expressed genes. Despite these shortcomings, scRNA-seq provides important insights for understanding the heterogeneity of gene expression within a cell population, or heterogeneity in underlying cell types within a mixed population. Both bulk RNA-seq and scRNA-seq still share the limitations of amplification bias and poor cDNA synthesis efficiency (51).

Another important point to note is that current studies use either ribosomal RNA depletion (ribodepletion) or poly(A) selection to enrich for RNA species of interest prior to library construction and subsequent sequencing. Each method is likely to result in differences in both the amount, representation and quality of the profiled RNA. With ribodepletion, ribosomal-RNA ( $r R N A$ ) is specifically depleted from an RNA sample so other RNA species (e.g. pre-mRNA and mature mRNA, circRNAs, IncRNAs, etc.) remain for downstream profiling. In contrast, poly(A) enrichment specifically isolates RNA species with (long) polyadenylated tails, a characteristic specific only to mature mRNAs. Thus, specific changes reported by various studies may be affected by the experimenter's choices in target RNA selection. It will be important to determine the impact of RNA selection on observed signatures of the aging transcriptome.

Impact of longevity interventions on the aging transcriptome Analysis of known longevity-extending dietary, genetic, and drug interventions suggest that key pathways that decline transcriptionally with aging may be rescued at least partly by these interventions $(52,53)$ (Table 3$)$. In this review, we focus on the transcriptional effects on common aging signatures of four well-characterized pro-longevity interventions: dietary restriction, Ames dwarfism, rapamycin supplementation, and metformin supplementation.

Dietary restriction (DR) refers to the limitation of either (i) 
Transcriptional remodeling in aging and longevity

Rochelle W. Lai, et al.

Table 3. Effects of longevity-promoting interventions on aging signatures

\begin{tabular}{|c|c|c|c|c|c|}
\hline Intervention & Tissue & Effect on aging signatures & Species & Profiling method & Reference \\
\hline \multicolumn{6}{|c|}{ Dietary interventions } \\
\hline \multirow{30}{*}{$\begin{array}{l}\text { Dietary } \\
\text { Restriction }\end{array}$} & \multirow[t]{10}{*}{ Liver } & Tissue & \multirow[t]{5}{*}{ Mouse } & RNA-seq & $(251)$ \\
\hline & & Decreases cell differentiation and maturation & & RNA-seq & \multirow[t]{2}{*}{$(53)$} \\
\hline & & Decreases protein metabolism & & ChIP-seq & \\
\hline & & Decreases transcription & & WGBS & $(52)$ \\
\hline & & $\begin{array}{l}\text { Prevents age-associated methylation changes } \\
\text { Slows epigenetic clock }\end{array}$ & & & \\
\hline & & Tissue & \multirow[t]{2}{*}{ Rat } & \multirow{2}{*}{ Western Blot } & \multirow[t]{2}{*}{$(252)$} \\
\hline & & Site specific acetylation at $\mathrm{H} 3 \mathrm{~K} 9, \mathrm{~K} 27$, and $\mathrm{K} 56$ & & & \\
\hline & & Cell (Hepatoma model) & \multirow[t]{3}{*}{ Mouse } & \multirow[t]{3}{*}{ RNA-seq } & \multirow[t]{3}{*}{$(253)$} \\
\hline & & Alters SIRT gene expression & & & \\
\hline & & Modifies accessibility of SIRT regulator region & & & \\
\hline & \multirow[t]{16}{*}{ Brain } & Hippocampus & \multirow[t]{13}{*}{ Mouse } & \multirow[t]{5}{*}{ RNA-seq } & \multirow[t]{5}{*}{$(254)$} \\
\hline & & Tissue & & & \\
\hline & & Alters calcium signaling & & & \\
\hline & & Alters axonal guidance signaling & & & \\
\hline & & Alters corticotropin-releasing hormone signaling & & & \\
\hline & & Alters synaptic long-term potentiation & & \multirow[t]{8}{*}{ RNA-seq } & $(255)$ \\
\hline & & Alters neuronal CREB signaling & & & \\
\hline & & Alters G-protein coupled receptor signaling & & & \\
\hline & & Decreases senescence-associated secretory phenotype & & & \\
\hline & & Decreases energy regulation & & & \\
\hline & & Decreases inflammation & & & \\
\hline & & Decreases phagocytosis & & & \\
\hline & & Prevents age-related methylation changes & & & \\
\hline & & Whole Brain & Mouse & Western Blot & $(256)$ \\
\hline & & Tissue & & & \\
\hline & & Attenuates age-associated reduction in histone methylation & & & \\
\hline & Adipose & Tissue & Mouse & Microarray & $(257)$ \\
\hline & & Decreases inflammation & & Western Blot & $(258)$ \\
\hline & & Decreases necroptosis & & RNA-seq & \\
\hline & & $\begin{array}{l}\text { Increases stem cell maintenance } \\
\text { Increases vascularization }\end{array}$ & & & \\
\hline Genetic & & & & & \\
\hline Ames Dwarfism & Liver & Tissue & Mouse & RNA-seq & (53) \\
\hline & & Alters methionine metabolism & & ChIP-seq & \\
\hline & & Attenuates age-associated hypermethylation & & WGBS & $(52)$ \\
\hline & & Decreases glycine-N-methyltransferase & & Microarray & $(68)$ \\
\hline & & $\begin{array}{l}\text { Increases glutathione } \\
\text { Increases mRNA expression of DNMT1 and DNMT3a }\end{array}$ & & Western Blot & $(66)$ \\
\hline & & Increases urea cycle proteins & & & \\
\hline & & Prevents age-associated miRNA expression changes & & & \\
\hline & & Slows epigenetic clock & & & \\
\hline & & Stabilized epigenome according to chronological age & & & \\
\hline & & Suppresses cell development and identity & & & \\
\hline & & Suppresses polyamine metabolism & & & \\
\hline & Serum & Cell & Mouse & RNA-seq & $(67)$ \\
\hline & & Modulates insulin signaling & & & \\
\hline & & Modulates MAPK signaling & & & \\
\hline & & Modulates mTOR signaling & & & \\
\hline & & Modulates Wnt signaling & & & \\
\hline & & Prevents age-associated miRNA expression changes & & & \\
\hline Drug & & & & & \\
\hline Rapamycin & Liver & Tissue & Mouse & WGBS & $(52)$ \\
\hline & & Prevents age-associated methylation changes & & RNA-seq & (53) \\
\hline & & Slows epigenetic clock & & ChIP-seq & \\
\hline & Brain & Tissue & Mouse & Western Blot & $(256)$ \\
\hline & & Attenuates age-associated histone modifications & & & \\
\hline Metformin & Liver & Tissue & Mouse & Microarray & $(259)$ \\
\hline & Muscle & Attenuates expression of NF-kB & & & \\
\hline & & Increases anti-inflammatory genes & & & \\
\hline & & Improves stress response & & & \\
\hline & & Increases antioxidant response & & & \\
\hline
\end{tabular}


the total caloric intake or (ii) specific nutrients, in each case without malnutrition (54). Typically, caloric restriction (CR) is achieved by a 25 to $60 \%$ reduction of calories from ad libitum controls in model organisms $(54,55)$. By altering nutrient sensing pathways, DR has been proposed to modulate downstream gene expression to extend longevity (56). CR-specific modulations may partly rescue transcriptional aging through upregulation of DNA methyltransferase activity, histone methylation, and histone deacetylation via HDAC1 and SIRT1 (57). These transcriptional changes have been observed to affect the development of cancer, diabetes, cardiovascular diseases, neurodegenerative diseases, and immune deficiencies in rodents, nonhuman primates, and humans (57). In the case of specific nutrient restriction, limitation of dietary protein or specific amino acids (i.e. asparagine, glutamate, methionine, tryptophan) yield the most robust longevity extension across metazoans (55, 58-62). Particularly with methionine restriction, the decrease in methionine-derivatives, such as methyl donor S-adenosylmethionine, may modulate DNA methylation in a protective manner against age-related neoplastic disease $(63,64)$. Notably, key downstream pathways reversed by these interventions at the gene expression level include a decrease in inflammatory processes, and the prevention of age-associated epigenetic changes (Table 3). These observations are compatible with the notion that dietary restriction can rescue aspects of aberrant age-related transcriptional remodeling.

The Ames dwarf mouse is a well-established longevity model (65). Because of a single nucleotide mutation in the Prop1 gene, Ames dwarf mice lack the transcription factor responsible for pituitary gland cell differentiation (65). Thus, Ames dwarf mice exhibit reduced levels of circulating growth hormone, prolactin, and thyroid-stimulating hormone (66). These altered hormone levels can lead to non-autonomous changes in the transcriptional profile, potentially promoting longevity through increased insulin sensitivity and reduced oxidative stress (65). Most notably, these changes include DNA methylation and microRNA regulation (53, 66-68). Analogous to the effect of dietary restriction, the Ames dwarf mouse also displays a more stable epigenome throughout life (52).

Rapamycin and metformin supplementation are two of the most widely studied pharmaceutical pro-longevity interventions (69). These two drugs are thought to increase animal longevity by acting as CR mimetics (70). Rapamycin is an inhibitor of the mammalian target of rapamycin (mTOR), a kinase that regulates cell growth in response to nutrients, growth factors, cellular energy, and stress (71). In a fed state, mTOR is activated to initiate protein synthesis, whereas mTOR inhibition with rapamycin mimics a fasting state (70). Halting protein synthesis arrests cell growth, which may explain why rapamycin has been shown to slow aging and neoplastic proliferation (72). At the transcriptional level, rapamycininduced mTOR inhibition slows the aging methylome $(52,53)$.
Metformin is a prevalent anti-hyperglycemic drug that primarily works by uncoupling the electron transport chain, thereby mimicking a fasted/low-energy state and stimulating adenosine monophosphate-activated protein kinase (AMPK) (73). When activated, AMPK phosphorylates key nuclear proteins, thereby regulating metabolic gene expression at the transcriptional level to make energy more available through catabolism in response to the fasted state (74). To note, AMPK activation is just one of the molecular effects of metformin, and it is thought that it may also act through other not fully understood pathways as well (70). In essence, rapamycin and metformin seem to mimic aspects of DR at both the translational and transcriptional level.

Limitations of creating a translational therapeutic derived from these animal interventions include difficulty in diet accountability, ethics of gene editing, pharmaceutical toxicity, and potential side effects. However, understanding the transduction pathways of longevity promoting interventions in animals will be key to ultimately apply and translate these interventions to humans.

\section{Transcriptional variability in aging and longevity}

Accumulating evidence supports a model where the transcriptome becomes less tightly reagulated throughout the aging process. Indeed, a progressive degradation of transcriptional networks robustness and integrity has been observed during aging in C. elegans (75) and in mouse tissues $(76,77)$. There is still a debate on the prevalence of increased cell-to-cell transcriptional noise in aging cells. Pioneering studies examined the impact of aging on the cell-to-cell levels of expression of a handful of genes $(78,79)$. Whereas increased transcriptional noise was observed in aging mouse cardiomyocytes (11 out of 15 tested genes) (78), no changes in transcriptional noise were detected in hematopoietic stem cells isolated from old mice (6 assayed genes) (79). Importantly, existing technical limitations limited the reach of these studies to few genes and cell types, thus making generalizations difficult.

As discussed above, recent advances in microfluidics have enabled genome-wide single-cell profiling across diverse cell types at high-resolution (47), and will be key to understand the biological impact of transcriptional noise regulation with age. Indeed, two recent studies have leveraged single-cell RNA-seq to query potential changes in cell-to-cell transcriptional noise with aging. Enge et al. profiled cells from the human pancreas, revealing that islet endocrine cells from older donors presented increased transcriptional noise, as well as signs of cell identity drift (50). Modulation of cell-to-cell noise with aging may also be context-specific. Indeed, a recent study in mice found that cell-to-cell transcriptional noise was increased upon immune stimulation in naive and effector memory CD4 + T cells from two subspecies of aging mice (80), whereas the opposite was observed in young cells. Together, these emerging discoveries are consistent with the notion that 
increased cell-to-cell transcriptional noise may be an important feature of mammalian aging.

\section{REMODELING OF THE TRANSCRIPTIONAL SPLICING LANDSCAPE WITH AGING AND IN LONGEVITY}

\section{Alternative splicing in the regulation of aging and longevity}

A large majority of metazoan genes are transcribed into precursor mRNAs (pre-mRNAs), which are constituted of exons separated by introns, and are thus known as "multi-exonic genes". Intronic regions are usually spliced to yield a mature mRNA transcript through the action of a nuclear enzymatic ribonucleoproteic complex, known as the "spliceosome", which recognizes specific target sequences found at exon/intron boundaries (81). It is generally thought that most introns are spliced out constitutively. However, many splicing signals can be used in a context-dependent manner, which can lead to the emergence of alternatively spliced isoforms (81).

Importantly, nearly all multi-exonic genes are subject to some degree of alternative splicing in one or more cell types ( $>95 \%$ of multi-exon transcripts in human cells), which increases the coding potential and regulatory complexity of metazoan genomes $(77,82)$. This mode of regulation depends on regulation by the core slicing machinery, which relies on sequence signals in cis and trans to either promote or repress splicing at such alternative sites (81). The coupling between multiple regulatory layers and context-driven selection of relevant splice sites results from exquisite regulation by input signals at multiple levels. Recent research advances have revealed that core components of the constitutive and alternative splicing machinery (i.e. the spliceosome) are actually involved in fine-tuning of the splicing landscape (reviewed in (81)).

Though splicing control may be thought of as a core essential process, emerging evidence suggests that its modulation may have key impacts on health and longevity. Indeed, splicing deregulation has been associated with a number of diseases, including age-related diseases (e.g. progeria, Alzheimer's, etc.) $(83,84)$. In addition, functional enrichment analyses on age-related human transcriptome remodeling have revealed significant changes in the expression of genes associated to genesets 'mRNA binding', 'mRNA processing', and 'RNA splicing' (85). Profound changes in the alternative splicing landscape with aging have been observed in mouse and human brain regions (86-88), with significant splicing deregulation in $\sim 40 \%$ of genes expressed in the human brain (88). Interestingly, Mazin et al. found that aging was associated to increased exon retention in human prefrontal and cerebellar cortex, which may result in increased targeting of the affected transcripts to Nonsense Mediated Decay (NMD) (88). To note, there seems to be little correlation between genes affected at the level of transcription and those affected at the level of slicing in aging (86).
Age-related splicing defects are also largely detected in brains from patients with neurodegenerative disorders compared to healthy controls $(84,87)$, which is consistent with the observation that these diseases have increased prevalence with age. Changes in the alternative splicing landscape with mammalian brain aging have been associated with carbohydrate metabolism and DNA repair (87), or neuronal function (86). Importantly, a recent study using hepatic tissue from rhesus monkeys subjected to $30 \% \mathrm{CR}$ showed that alternative splicing was central to the response to nutrient restriction and integral to the associated metabolic reprogramming (89).

Supporting the hypothesis that splicing dysfunction may directly impact the aging process, a recent study found that differences in splicing factor spleen expression and changes to alternative splicing were associated with strain lifespan across 6 genetically distinct mouse strains (90). This finding is consistent with the fact that expression levels of splicing regulators hnRNPA1 and A2 were positively associated to increased parental longevity in the InCHIANTI human aging study (90). Importantly, the rewiring of the splicing machinery and potential imbalance of splicing factors may have a direct impact on organismal aging and longevity. Indeed, a recent study has found that, in the worm C. elegans, Splicing Factor 1 (SFA-1) plays a key role in modulating longevity upon DR (91). Importantly, stable overexpression of SFA-1 led to increased worm longevity, whereas SFA-1 depletion impacted the activity of components of the TORC1 pathway that are normally subjected to alternative splicing (91).

Thus, accumulating evidence suggests that splicing alterations may be a hallmark of aging transcriptome. This progressive loss of the ability to fine-tune gene expression in aging cells is likely to have a profound effect on the physiology of aging cells. Alternative splicing, as regulated by splicing factors, may represent an important regulator or early marker of longevity, which deserves further systematic study.

\section{Long non-coding RNAs in the regulation of aging and in longevity}

Thousands of long noncoding RNA (IncRNA) transcripts have now been identified, most of which with yet unknown biological functions (92). Although these transcripts were initially thought to be non-coding (hence their name), accumulating evidence has shown that they in fact harbor a wealth of small open reading frames that can give rise to small functional peptides $(93,94)$. In addition, emerging evidence suggests that long non-coding RNAs (IncRNAs) may act as aging biomarkers, and perhaps even influence the aging process (95). Emerging studies have focused on exploring the roles of specific IncRNAs in aging of different cell types. Specifically, the $H 19$ IncRNA was recently demonstrated to be involved in vascular endothelial cell aging through inhibition of the Stat 3 signaling pathway (96). In addition, control of H19 levels is key to maintain adult HSC quiescence (97), thus 
preventing a premature depletion of the stem cell pool. Moreover, the IncRNA FLJ46906 may regulate the expression of various aging-associated genes (e.g. TGFB1, CXCL8, IL1B, IL6, and ELN) through modulation of the NF-KB and AP-1 transcription factors in human fibroblasts (98). Thus, because of the abundance of IncRNAs in vertebrate genomes, it is likely that many of them may play important roles in adult tissue homeostasis and regulation of the aging process. Future studies are needed to shed light on IncRNAs as candidate regulators of the aging transcriptional landscape.

\section{Circular RNAs: exciting new players of the aging transcriptome?}

Circular RNAs (circRNAs), which are covalently closed circular RNAs without a free 5'- or 3'- end, were first identified in viruses by electron microscopy (99). A few years later, they were found in eukaryotic cells, although they were then dismissed as likely insignificant byproducts (100). With the recent emergence of ultra-high-throughput Next Generation Sequencing (NGS), further investigation into transcriptomic landscapes has become possible on an unprecedented scale. Indeed, deep RNA-seq in human cells revealed that circRNAs may even sometimes represent the major transcript isoforms of many genes (101). Indeed, circRNAs are abundant, and largely expressed in a tissue-specific manner $(102,103)$. Moreover, recent studies have identified circRNAs across tissues and species (e.g. human, mouse, Drosophila, C. elegans, Tree Shrew, etc.) $(101,104-106)$. Circular RNAs are thought to be generated through an original alternative splicing mechanism, known as "back-splicing", where the spliceosome covalently bonds the downstream $5^{\prime}$ donor site of an exon to the upstream 3' acceptor site of another (upstream) exon (107), which may be a promoter by the proximity of transposable element sequences (102). Since the rediscovery of circRNAs in mammalian cells, the cellular roles of these RNAs have been under scrutiny. Studies have found evidence that circRNAs can act as 'microRNA sponges' (108), promoting microRNAdirected RNA degradation (109), trapping RNA-binding proteins (110), or even act as templates for protein translation through the presence of Internal Ribosome Entry Sites (IRES) (111-113). For example, one of the best- studied circRNA species to date is derived from antisense transcription from the CDR1 locus, and known as CDR1as, which harbors $\sim 70$ conserved miR-7 target sites, and can function as a miRNA sponge (108). Because of the ability of some circRNAs to act as miRNA sponges, they are now widely thought to constitute a class of competing endogenous RNA (108).

This emerging class of RNAs has recently been gaining traction in the aging field, notably because many circRNAs have been observed to be differentially expressed in aging neural tissue across species $(104,106,114,115)$. In Drosophila, 262 circRNAs expressed in the Central Nervous Systems (CNS) were found to be upregulated between 1 and 20 days of life (104). Accumulation of circRNA in neural tissue was also observed in mice (115), with $\sim 5 \%$ of brain circRNAs significantly up-regulated with age whereas only $\sim 1 \%$ were significantly downregulated with age (1 vs. 22 months) (115), although the young control of that study may have still been showing transcriptional signatures of a developing brain. Those results are consistent previous observations did in Drosophila, but, the young mice used can be considered as pre-developmental mice. All the changes in circRNA levels may be due to development and not aging at this age. Future studies would require young post-developmental mice for any comparisons. A recent study found that a global, ageassociated, accumulation of circRNAs can also be observed in C. elegans (105). About 90\% (1052/1166) of measured circRNAs were observed to be up-regulated at day 10 of life compared the L4 larval stage, whereas 37 circRNAs were observed to be significantly down-regulated (105). Cortes-Lopez et al. proposed that this accumulation of circRNAs may be the result of their increased stability and the fact that most of $C$. elegans' cells are post-mitotic cells (105). It is important to note that, so far, circRNAs have only been observed to accumulate in adult $C$. elegans and mammalian brains, both of which are enriched in post-mitotic cells. However, those studies do not include spike-in to control the analysis and to conclude accumulation of circRNAs with aging (116).

While functional studies of the roles of circRNAs are still lacking in the context of aging research, the downregulation of circRNA circPVT1 was found to be critical for the establishment of cell senescence in human fibroblasts, through its interaction with microRNA let-7 (117). Although this is not strictly representative of organismal aging, senescent cells do accumulate over the course of lifespan (118), and clearance of these cells leads to improved health and lifespan (119). More generally, the functional impact of circRNA regulation on cells and organisms is still very much an open field of study. Importantly, emerging work suggest that they may be key for normal brain function, since the specific depletion of Cdr1as in mice was associated with neuropsychiatric dysfunction (120). The study of circRNA regulation and its impact on organismal physiology is still very much in its infancy, and additional gain and loss-of-function studies for circRNA genes will be needed in adult organisms to shed light on their potential role in health and lifespan.

\section{TRANSPOSABLE ELEMENTS AND ENDOGENOUS RETROVIRUSES: THE SILENT KILLERS WITHIN THE EUKARYOTIC GENOME?}

Genomic instability is characterized by an accumulation of somatic mutations, including de novo insertions of transposable elements (TEs) (121). TEs, which have also been dubbed "jumping genes," are a type of repetitive DNA that has the capacity to transpose from one genomic location to another (122). TEs constitute anywhere from 3\% in Saccharomyces cerevisiae to $77 \%$, in Rana esculenta, of eukaryotic genomes 
Transcriptional remodeling in aging and longevity

Rochelle W. Lai, et al.

Table 4. Impact of transposable elements in health and disease

\begin{tabular}{|c|c|c|c|c|c|c|}
\hline Organism & $\begin{array}{l}\text { Cell lines / Cell } \\
\text { Types / Tissues }\end{array}$ & Transposon name & $\begin{array}{l}\text { How were they } \\
\text { measured? }\end{array}$ & $\begin{array}{c}\text { Changes observed in } \\
\text { Transposons }\end{array}$ & $\begin{array}{l}\text { Phenotypes associated } \\
\text { with the listed change }\end{array}$ & Reference \\
\hline $\begin{array}{l}\text { Drosophila } \\
\text { melanogaster }\end{array}$ & Fat body & $\begin{array}{l}\text { Multiple Retro } \\
\text { transposons }\end{array}$ & $\begin{array}{l}\text { qPCR, RNA- seq, } \\
\text { Immunofluorescence } \\
\text { microscopy }\end{array}$ & $\begin{array}{l}\text { Increase in expression } \\
\text { with age }\end{array}$ & Aging & $(260)$ \\
\hline $\begin{array}{l}\text { Drosophila } \\
\text { melanogaster }\end{array}$ & Heads & LINE-1, Gypsy & $\begin{array}{l}\text { qPCR, } \\
\text { Immunochemical } \\
\text { staining }\end{array}$ & $\begin{array}{l}\text { Increase in expression } \\
\text { of TEs }\end{array}$ & Aging & (169) \\
\hline Mus musculus & $\begin{array}{l}\text { Tissue }(\mathrm{C} 57 \mathrm{BL} / 6) \\
\text { from Aged } \\
\text { Rodent Tissue } \\
\text { Bank \& NIA } \\
\text { Aged Rodent } \\
\text { Colonies }\end{array}$ & LINE-1 \& MusD & $\begin{array}{l}\text { Nuclease Sensitivity, } \\
\text { oligo-dT } \\
\text { immuno-FISH } \\
\text { staining, RNA-seq, } \\
\text { qPCR }\end{array}$ & $\begin{array}{l}\text { Increase in copy } \\
\text { numbers of LINE-1 \& } \\
\text { MusD } \\
\text { retrotransposons in } \\
\text { liver and muscle }\end{array}$ & $\begin{array}{l}\text { Increase in somatic } \\
\text { retro-transposition } \\
\text { with age }\end{array}$ & $(261)$ \\
\hline Mus musculus & $\begin{array}{l}\text { ES cell culture, } \\
\text { embryos, } \\
\text { 2C-GFP ES cell } \\
\text { line }\end{array}$ & LINE-1 & $\begin{array}{l}\text { RNA-FISH, RNA-seq, } \\
\text { RT-qPCR, ChIP Assay, } \\
\text { Immunofluorescence } \\
\text { analysis, co- } \\
\text { immunoprecipitation }\end{array}$ & LINE-1 inhibition & $\begin{array}{l}\text { Inhibited embryonic } \\
\text { stem cell self-renewal } \\
\text { and impaired embryo } \\
\text { development }\end{array}$ & (175) \\
\hline Homo sapiens & $\begin{array}{l}\text { Oocyte and } \\
\text { embryo }\end{array}$ & $\begin{array}{l}\text { HERVL } \\
\text { retrotransposons }\end{array}$ & $\begin{array}{l}\text { RNA-seq, } \\
\text { Immunofluorescence } \\
\text { Imaging }\end{array}$ & $\begin{array}{l}\text { HERVL and MLT2A1 } \\
\text { repeat elements are } \\
\text { transiently expressed } \\
\text { during the cleavage } \\
\text { stage }\end{array}$ & $\begin{array}{l}\text { DUX4 potentially } \\
\text { activating the } \\
\text { cleavage stage genes } \\
\text { and repetitive } \\
\text { elements }\end{array}$ & $(262)$ \\
\hline Homo sapiens & iPSC culture & $\begin{array}{l}\text { HERVL } \\
\text { retrotransposons }\end{array}$ & $\begin{array}{l}\text { RNA-seq, Luciferase } \\
\text { Assay, ChIP-Seq, } \\
\text { RT-qPCR }\end{array}$ & $\begin{array}{l}\text { HERVL and MLT2A1 } \\
\text { repeat elements are } \\
\text { transiently expressed } \\
\text { during the conversion } \\
\text { of cleavage stage }\end{array}$ & $\begin{array}{l}\text { DUX4 potentially } \\
\text { activating the } \\
\text { cleavage stage genes } \\
\text { and repetitive } \\
\text { elements }\end{array}$ & $(262)$ \\
\hline Mus musculus & ES cell culture & $\begin{array}{l}\text { MERVL } \\
\text { retrotransposons }\end{array}$ & $\begin{array}{l}\text { RNA-seq, ATAC-seq, } \\
\text { ChIP-Seq and } \\
\text { Immunofluorescence } \\
\text { and Imaging }\end{array}$ & $\begin{array}{l}\text { Conversion mESCs to a } \\
\text { 2C-like state when } \\
\text { MERVL peaks }\end{array}$ & $\begin{array}{l}\text { Murine DUX activating } \\
\text { the cleavage stage } \\
\text { genes }\end{array}$ & $(262)$ \\
\hline Homo sapiens & HeLa M2cell line & LINE-1 & $\begin{array}{l}\text { Mass Spectrometry, } \\
\text { Immunofluorescence } \\
\text { staining, RNA-FISH, } \\
\text { Western }\end{array}$ & $\begin{array}{l}\text { Peaks during } \mathrm{S} \text { phase } \\
\text { of the cell division }\end{array}$ & N/A & (263) \\
\hline Homo sapiens & $\begin{array}{l}\text { Adipose derived } \\
\text { stem cells } \\
\text { (ADCS) }\end{array}$ & Alu/SINE & $\begin{array}{l}\text { Immunofluorescence, } \\
\text { qPCR, ChIP-Seq, } \\
\text { Northern } \\
\text { Hybridization }\end{array}$ & $\begin{array}{l}\text { Knockdown of } \\
\text { Alu/SINE in } \\
\text { senescent cells }\end{array}$ & $\begin{array}{l}\text { Initiates self-renewal of } \\
\text { the cells }\end{array}$ & $(264,265)$ \\
\hline $\begin{array}{l}\text { Drosophila } \\
\text { melanogaster }\end{array}$ & $\begin{array}{l}\text { dAgo2 mutated } \\
\text { heads }\end{array}$ & LINE-1, Gypsy & $\begin{array}{l}\text { Western Blots, qPCR } \\
\text { Immunochemical } \\
\text { staining, GFP Imaging }\end{array}$ & $\begin{array}{l}\text { Increase in expression } \\
\text { of TEs }\end{array}$ & Neuronal decline & (169) \\
\hline Homo sapiens & H9 ESCs cell line & LINE-1 & $\begin{array}{l}\text { RT-qPCR, Retro } \\
\text { transposition Assay, } \\
\text { TUNEL analysis, } \\
\text { Western Blot }\end{array}$ & $\begin{array}{l}\text { LINE-1 increases when } \\
\text { TREX1 decrease }\end{array}$ & Neuroinflammation & (266) \\
\hline $\begin{array}{l}\text { Homo sapiens } \\
\text { (ROSMAP } \\
\text { project) }\end{array}$ & Brain & Multiple TEs & $\begin{array}{l}\text { RNA-seq, PCR, H3KAc } \\
\text { ChIP-seq }\end{array}$ & $\begin{array}{l}\text { Tau levels correlate } \\
\text { with transposon } \\
\text { levels }\end{array}$ & Alzheimer's & (180) \\
\hline $\begin{array}{l}\text { Drosophila } \\
\text { melanogaster } \\
\text { (Transgenic } \\
\text { flies) }\end{array}$ & Brain & Multiple TEs & qPCR, RNA-seq & $\begin{array}{l}\text { As Tau is expressed, } \\
\text { transposon } \\
\text { expression increases }\end{array}$ & Alzheimer's & (180) \\
\hline
\end{tabular}


Table 4. Continued

\begin{tabular}{|c|c|c|c|c|c|c|}
\hline Organism & $\begin{array}{l}\text { Cell lines / Cell } \\
\text { Types / Tissues }\end{array}$ & Transposon name & $\begin{array}{l}\text { How were they } \\
\text { measured? }\end{array}$ & $\begin{array}{l}\text { Changes observed in } \\
\text { Transposons }\end{array}$ & $\begin{array}{l}\text { Phenotypes associated } \\
\text { with the listed change }\end{array}$ & Reference \\
\hline $\begin{array}{l}\text { Drosophila } \\
\text { melanogaster } \\
\text { (Transgenic } \\
\text { flies) }\end{array}$ & Head Tissues & gypsy ERV & qPCR, RNA-seq & $\begin{array}{l}\text { Neuronal and glial } \\
\text { hTDP-43 expression } \\
\text { exhibits elevated } \\
\text { expression of gypsy } \\
\text { ERV }\end{array}$ & $\begin{array}{l}\text { Neurodegeneration in } \\
\text { diseases such as } \\
\text { Amyotrophic lateral } \\
\text { sclerosis (ALS) and } \\
\text { frontotemporal lobar } \\
\text { degeneration (FTDL) }\end{array}$ & (183) \\
\hline Homo sapiens & Brain & Multiple TEs & RNA-seq, RT-qPCR & $\begin{array}{l}\text { Increased repetitive } \\
\text { element } \\
\text { accumulation in } \\
\text { C9orf72 positive } \\
\text { cases }\end{array}$ & $\begin{array}{l}\text { Neurodegeneration in } \\
\text { diseases such as } \\
\text { Amyotrophic lateral } \\
\text { sclerosis (ALS) and } \\
\text { frontotemporal lobar } \\
\text { degeneration (FTDL) }\end{array}$ & (267) \\
\hline $\begin{array}{l}\text { Rattus } \\
\text { norvegicus }\end{array}$ & Cortical neurons & Multiple TEs & RIP-seq & $\begin{array}{l}\text { TDP-43 binds to } \\
\text { transposons }\end{array}$ & $N / A$ & $(182,268)$ \\
\hline Mus musculus & Brain & Multiple TEs & mRNA-seq, CLIP-seq & $\begin{array}{l}\text { Depletion of TDP-43 } \\
\text { in mice increases } \\
\text { transposon } \\
\text { expression, } \\
\text { TDP-43 binds to } \\
\text { transposons }\end{array}$ & N/A & $(182,269)$ \\
\hline $\begin{array}{l}\text { Mus musculus } \\
\text { (transgenic) }\end{array}$ & Spinal cord & Multiple TEs & mRNA-seq & $\begin{array}{l}\text { Increase in expression } \\
\text { of transposons when } \\
\text { TDP-43 was } \\
\text { overexpressed }\end{array}$ & N/A & $(182,270)$ \\
\hline Homo sapiens & Brain & Multiple TEs & CLIP-seq & $\begin{array}{l}\text { Decreased binding of } \\
\text { transposons to } \\
\text { TDP-43 }\end{array}$ & $\begin{array}{l}\text { Frontotemporal lobar } \\
\text { degeneration (FTDL) }\end{array}$ & (182) \\
\hline Mus musculus & $\begin{array}{l}\text { Lymphoma and } \\
\text { hepatoc ellular } \\
\text { carcinoma } \\
\text { tumors }\end{array}$ & LINE-1 and MusD & qPCR & $\begin{array}{l}\text { Copy number } \\
\text { increases compared } \\
\text { to control tissue }\end{array}$ & Cancer & (261) \\
\hline Homo sapiens & Many tissue types & LINE-1 & Immunohistochemistry & $\begin{array}{l}\text { Present in the } \\
\text { cancerous tissue } \\
\text { types; mostly absent } \\
\text { in healthy tissue }\end{array}$ & Cancer & (271) \\
\hline Homo sapiens & Blood & $\begin{array}{l}\text { AAlu/SINE and } \\
\text { LINE-1 }\end{array}$ & MethyLight PCR & $\begin{array}{l}\text { Transposon } \\
\text { methylation status is } \\
\text { inversely correlated } \\
\text { with menopausal age }\end{array}$ & $\begin{array}{l}\text { Earlier menopause is } \\
\text { associated with earlier } \\
\text { onset of age-related } \\
\text { disorders }\end{array}$ & (140) \\
\hline
\end{tabular}

(123). In vertebrates specifically, the proportion ranges from $6 \%$ in the green spotted pufferfish to $55 \%$ in the zebrafish (124). These elements are highly diverse in terms of DNA sequences, mobilization mechanisms, and regulatory mechanisms (reviewed in $(125,126)$. Two main classes of transposons have been described: (i) Class I transposons, or RNA-mediated transposons, and (ii) Class II transposons, or DNA-mediated transposons (127). Class I TEs transpose through a "copy and paste" mechanism, generating RNA intermediates that can be reverse transcribed and integrated into the genome at a new site (127). In contrast, Class II transposons rely on enzymes that "cut" the transposon DNA sequences out of their current loci, and "paste" them elsewhere in the genome (127). Because of their mobility, TEs can act as mutagens and have the potential to disrupt genes by inserting themselves into coding sequences and to change gene expression through insertion into regulatory sequences (128). From a bioinformatics perspective, the repetitive nature of TEs have complicated genomic analyses, as short-read NGS technologies have limited ability to distinguish different insertions of the same element family (129). Though $>44,000$ sequences have been catalogued on Repbase, a database for repetitive elements (130), it is likely that many more remain to be characterized. Fortunately, the emerging availability and reduced cost of long-read sequencing technologies (e.g. Pacific Biosciences SMRT sequencing (131), Oxford Nanopore (132)) should help overcome these technical hurdles in the coming years $(133,134)$. Ultimately, the high sequence and functional 
variability of transposons means that much remains to be discovered in terms of their mechanisms, roles, and biological consequences, and accumulating evidence suggests that they play a key role during aging and in the pathogenesis of age-related diseases (Table 4).

\section{Transposon landscapes in traditional and emerging model systems}

A number of invertebrate animal models, including C. elegans and $D$. melanogaster, and some vertebrate models, such as the mouse and the zebrafish, have been used in aging and transposable element research (135). Noteworthy, TEs vary in type and in frequency across different organisms. For example, $12 \%$ of the C. elegans genome is composed of TEs (136), most of which ( $\sim 95 \%)$ are DNA transposons (124). In contrast, TEs encompass $\sim 20 \%$ of the $D$. melanogaster genome (137), and LTRs from the gypsy, copia, and Pao families are the most abundant (138). In humans, $\sim 50 \%$ of the genome is repetitive, with the majority of human TEs being LINE-1 elements ( $\sim 17 \%$ of the genome) (139). Although invertebrate models have been widely used in studies on transposon and aging processes due to, among other factors, their short lifespans, this has come at the expense of knowledge concerning the relationship between these processes and vertebrate-specific genes, organs and tissues, and physiological processes. For example, methylation status of transposon loci in human blood has been identified as a predictor of menopausal age (140), and transposons have also been shown to induce responses mediated by interferons (141), which are modulators of innate and adaptive immunity.

Though aging studies can be, and have been, carried out in vertebrate models such as the mouse and the zebrafish, their relatively long lifespans in the laboratory (3-4 and 5 years, respectively) make aging studies costly and time-consuming. Consequently, there has been a need for a tractable short-lived vertebrate model to address these limits. The African turquoise killifish (Nothobranchius furzeri) is a naturally short-lived vertebrate $(\sim 0.5$ year), which was first found and collected from ephemeral ponds in Mozambique and Zimbabwe (142-145). Other advantages of this model are the availability of several wild-derived strains (146-148), an annotated draft genome sequence $(142,149)$ and a rapid genome-editing toolkit (143). In addition, despite a compressed lifespan, the turquoise killifish shows classical phenotypes of vertebrate aging (e.g. cognitive impairment, histological changes, telomere shortening, and mitochondrial dysfunction) (150-153). Relevant to the study of TEs in vertebrate aging, $45-65 \%$ of the turquoise killifish genome is composed of TEs, a proportion which is similar to that of the human genome (154). Moreover, the elements seem to be transcriptionally active, compatible with the notion of active transposition across tissues in this species (142). Given all of these characteristics, we anticipate that the African turquoise killifish will be an important model to understand the mechanisms and impact of TE regulation in aging and age-related diseases.

\section{Mechanisms and breakdown of TE regulation throughout lifespan}

Given the mutagenic potential of unfettered transposition, cells have evolved layers of pre- and post-transcriptional mechanisms to restrain transposon activity in the germline and somatic tissues $(125,126)$. Known pre-transcriptional mechanisms mainly include DNA methylation and TE heterochromatinization $(125,155)$. For instance, in female Drosophila head tissues and fat bodies, Wood et al. found that overexpression of genes encoding chromatin modifying enzymes Sir2 and Su(var)3-9 led to repression of the age-related increase in TE expression (156). Sir2 is an NAD-dependent deacetylase involved in gene silencing at heterochromatic regions in yeast and flies (157-159), while Su(var)3-9 catalyzes the methylation of Lysine-9 of histone H3 (H3K9) to repress transcription (160). The study also found that overexpression of Su(var)3-9 was associated with increased lifespan (156). Another study noted a global increase in heterochromatin in the livers of old mice (based on DNase I sensitivity assay and comet tail assay), but associated increased expression of TEs with relaxed heterochromatic regions (161). Although the global increase in heterochromatin in this specific context runs counter to the "loss of heterochromatin" model of aging (162), TE activation has, in contrast, been shown to be recurrently associated with heterochromatin loss in C. elegans, D. melanogaster, mice, and mammalian cells $(163,164)$. Additionally, in senescent human fibroblasts, chromatin accessibility was shown to increase at TE insertion loci, thus promoting TE transcription and active transposition (161).

Current research is partially focused on identifying novel genetic regulators of transposon activity. A genome-wide CRISPR-Cas9 screen in the K562 and HeLa cancer cell lines was recently performed in order to identify novel regulators of LINE-1 retrotransposition unbiasedly (165). However, how these new TE regulators respond to aging and longevity intervention remains unknown. Accumulating evidence also highlights the interaction between the interferon response and TE activity. Type I interferons (IFNs) are a family of cytokines that modulate immunity against viruses and intracellular pathogens, notably by inducing genes that promote an "antiviral state", sensitizing these cells to apoptosis, and by activating immune cells that clear infected cells (166). Importantly, Yu et al. showed that LINE- 1 stimulates IFN- $\beta$ expression in in vitro human and mouse cell models (141). Conversely, treatment with IFN- $\beta$ could repress endogenous LINE-1 retrotransposition, with endogenous IFN- $\beta$ signaling counteracting replication of LINE-1 elements (141). An additional study looking for regulators of cell survival in human acute myeloid leukemia cell lines found that loss of heterochromatin regulator SETDB1 associated with lower cell viability, induction of TEs, and induction of viral response genes, including interferon stimulated genes (167). 
Post-transcriptional mechanisms of regulation rely on the degradation of TE RNAs or inhibition of their translation. These rely on siRNA, miRNA, and piRNA pathways (125, 155). Work by Wood et al. also assessed the relationship between siRNA activity and TE levels in Drosophila. They observed a repression of the age-associated TE upregulation in mutant flies overexpressing Dicer-2, an enzyme necessary for siRNA processing, or in flies hypomorphic for the Adar gene, which encodes the main RNA-editing enzyme and functions as a negative regulator of the siRNA pathway (156). Importantly, the presence of Alu elements is a major factor for selecting RNA-editing targets by ADAR in humans cells (168). In another Drosophila study focusing on the central nervous system, increased TE expression and transposition events were observed with aging using a gypsy GFP reporter (gypsy-TRAP reporter) (169). Interestingly, mutation of Ago2, another gene involved in RNAi pathways, led to increased TE activity and shortened lifespan (169). To note, although associations between RNAi pathways and TE activity have been noted, the results should be interpreted with caution, as dysregulation of RNAi pathways are likely to lead to a general misregulation of many downstream processes. Canonically, siRNA pathways and piRNA pathways have been thought to be primarily restricted to regulatory roles in somatic and germ line cells, respectively (138). Emerging evidence, however, suggests that piRNA mechanisms may also be active in somatic cells (170). In one type of mushroom body neuron in Drosophila, suppression of the piRNA proteins Aubergine and Argonaute3 was associated with elevated TE expression (171), and another study proposed that piRNA components may play a role in alternative splicing of transposable elements in both soma and germ line cells of the fly (172). A final form of regulation which remains loosely characterized involves tRNA-derived fragments which have been shown to target retrotransposon primer binding sites in mouse embryonic and trophoblast stem cells and may, more generally, inhibit transcription or induce RNAi pathways (173). Though multiple layers of native regulatory mechanisms for transposon control exist, research has also been focused on identifying dietary and pharmaceutical interventions that can supplement cellular mechanisms.

\section{Transposon activity modulation by dietary and chemical interventions}

One of the focuses of ongoing research is to identify dietary interventions or novel drugs that inhibit transposon activity and determining what impact these have on lifespan and health. In female Drosophila heads and fat bodies, DR suppressed the age-related increase in TE expression that was observed in the high calorie (HC) diet control group (156). Additionally, DR seemed to counteract the increase in expression of genes located in constitutive heterochromatin regions that occurred with age in HC-fed flies (156). A high-fat diet similarly promoted TE expression in the livers of middle-aged male mice, and the authors suggest that CR may inhibit these effects (174). Interestingly, knockdown of the chromatin-remodeler Chd1 led to similar transposon activation as the high-fat diet and aging conditions, supporting a key role for chromatin-level regulation of TE activity (174). Pharmacologically, Wood et al. demonstrated that treatment of flies with the reverse transcriptase inhibitor lamivudine repressed retrotransposition in Drosophila fat bodies and increased the lifespan of Dicer-2 mutants (156). Looking forward, the effects of this drug, and other anti-retroviral drugs, should be assessed when administered at different times in an organism's life to determine which dosing periods contribute most towards improving organism function and lifespan. In particular, embryogenesis may be an informative period to test, given that transposition events occurring during this time are likely to lead to large bulks of mutated cells in the body, thus leading to somatic chimerism (138). Importantly, since both avenues for TE regulation (i.e. inhibiting expression and inhibiting transposition) may not necessarily lead to the same outcome, both avenues should be explored in the treatment of aging and age-related diseases. For example, inhibition of LINE-1 with a reverse transcriptase inhibitor does not have the same developmental consequences for mouse embryonic stem cells as does a genetic knockdown (175). Since accumulating evidence suggests that transposon reactivation occurs with and in various age-related diseases (Table 4), it will ultimately be important to identify robust methods to modulate TE activation in vivo throughout life.

\section{Transposons: a blessing and a curse?}

The idea that TEs play both positive and negative roles, based on factors such as the time of activation and the integration site within the host genome, has been gaining traction (Table 4). Historically, TEs have been seen as 'genetic parasites' and 'selfish DNA' elements (176). Though some TEs can be described as such, others are non-functional and thus neutral, or have helped shape new functions at the cellular and organismal level (129). Since TEs contain regulatory elements that differentially respond to environmental and stress cues, TE insertions may help dynamic rewiring of gene regulatory networks, and generate novel spatiotemporal gene expression programs (126). Examples to illustrate the potential multi-pronged effects of transposons concern the human Endogenous Retrovirus (HERV) family of transposons. On the one hand, the proteins syncytin-1 and syncytin-2 - encoded by the HERV-W and HERV-FRD env genes - are required for fusion of trophoblast giant cells to form the syncytiotrophoblast, a key step for placental formation, and contribute to fetal immune tolerance (177). On the other hand, the viral properties of ERVs render them capable of activating the immune system, and this may contribute to the development of autoimmunity and other pathologies $(178,179)$.

Thus, the ERV families of transposons, and perhaps others, may have antagonistic pleiotropic effects, playing important roles in early development, but contributing to pathogenesis 
and functional decline post-development. A number of associations between transposons and different age-related disease states have been identified (see Table 4). In an intriguing example, Guo et al. identified an association between global TE levels and Tau pathological burden (180). Moreover, they found that Tau expression induces TE expression in a Drosophila model (180), raising the possibility that TEs may be causative agents or drivers of Alzheimer's disease and neurodegeneration. However, the mechanisms underlying this link are still unclear, and will deserve further consideration. Similarly, functionally abnormal TAR DNA-binding protein 43 (TDP-43) is observed in many cases of amyotrophic lateral sclerosis (ALS) and some cases of frontotemporal lobar degeneration (FLTD) (181). Experimentally, TDP-43 has been shown to bind transposable elements in mouse and rat models, differentially bind TEs in healthy and FTLD patients (182), and induce expression of a panel of transposons when human TDP-43 is expressed in Drosophila and mouse models $(182,183)$. The data in Drosophila suggests hTDP-43 toxicity may stem from gypsy ERV activating DNA damage-mediated programmed cell death (183), but whether this mechanism is conserved and whether it is the sole driving mechanism remains unclear.

Future work on the role of TE activity in aging and age-related diseases should seek to clarify this relationship by generating precise genomic tools. Ultimately, the field will need to address whether transposon activation is a byproduct or a driver of aging and disease and, if the latter is true, uncover the mechanisms by which this occurs.

\section{THE EMERGING IMPACT OF SMALL ncRNAs IN AGING AND LONGEVITY}

\section{miRNAs in the regulation of aging and longevity}

MicroRNA (miRNA) are a class of endogenous eukaryotic small non-coding RNAs, $\sim 22$ nucleotides long, that play a key role in RNA silencing and post-transcriptional regulation of gene expression (184). miRNAs are abundant and have been proposed to target, and potentially regulate, $\sim 60 \%$ of mammalian genes (185). Accumulating evidence suggests that remodeling of the miRNA expression landscape may be a biomarker, or even a driver, of the aging process (95).

Several pioneering studies have identified age-related changes in the miRNA transcriptional landscape across cells and tissues from various evolutionary taxa (i.e. worms, mouse, rats, human, macaque, African turquoise killifish, etc.) (186-198). Interestingly, miRNA with age-specific changes in C. elegans were shown to either promote or repress normal lifespan and stress resistance in the adult organism $(186,199)$. Further, expression levels of specific miRNA early in life can predict C. elegans longevity (187), supporting the notion that these changes may be responsible for aging phenotypes at least partly. Maturation of miRNA sequences from precursors requires Dicer expression (200). Intriguingly, a fat-specific Dicer ablation was found to lead to an accelerated aging phenotype in mice, and counteracted positive effect of DR (201). Moreover, transfection of age downregulated miRNAs into 18-month-old mice led to a partial rejuvenation of liver expression profiles, at least in terms of aging markers (e.g. p16INK4a) (190).

An interesting case is that of the miR-29 microRNA family. Indeed, members of this family were found to be upregulated with age in various tissues, including brain, muscle, skin, vascular tissue, heart, liver, lung and kidney (191, 193-198, 202). Age-related accumulation of DNA-damage has been proposed to activate miR-29 and p53 (195). It has also been proposed that miR-29 may be involved in a compensatory response limiting an age-related neuronal iron accumulation (196). Although miR-29 upregulation with aging seems ubiquitous, conditional knockdown for miR-29 in mouse brains led to an increase in male lifespan, while female lifespan was decreased (202), suggesting a complex interaction between miR-29 functions in health and lifespan and other factors (e.g. sex). Interestingly, a recent study found that TGF- $\beta$ could signal via miR-29 to promote repress the translation of the main H4K20me3 methyltransferases (203). Deficit in cellular H4K20me3, a chromatin mark which plays an important for DNA-damage repair, led to cellular senescence, and might contribute to mouse cardiac aging in vivo (203). These observations support the notion that a complex interplay of signaling between non-coding RNAs and the epigenome may be driving aspects of the aging process.

A potential role for tRNAs in aging and longevity regulation? The genetic code is degenerate, with the set of 20 amino acids encoded by 61 base triplets or codons (204). Hence, multiple synonymous codons can be used in coding sequences, giving rise to the inclusion of the same amino acid in the final protein product. Traditional studies of disease genetics and evolutionary selection have focused on non-synonymous variants, which lead to a change in protein sequence and, presumably, protein function. However, accruing evidence now supports the idea that codon choices, while not affecting the protein sequence, can impact translation by interacting with the tRNA pool (205), thus functionally modulating final protein products $(206,207)$. Recent examples of the consequences of codon usage biases include modulation of the transcription rate (208), of translation rate (209) or selection against protein misfolding (210). In turn, these processes have been involved in the pathogenesis of neurodegenerative diseases (211-213), and their modulation may be involved in the age-related proteostasis collapse (6). Almost 50 years ago, researchers theorized that changes in the tRNA pool with life or development may result in an otherwise unnoticed role for codon usage bias in aging (214). However, the importance of changes in tRNA pools, and their interactions with codon usage, on aging and lifespan is still largely unknown.

Accumulating evidence showing time and tissue variability of the tRNA pool have led to rekindled interest in this 
intriguing hypothesis $(215,216)$. Because of the generally accepted importance of translation regulation and proteostasis with aging (6), the impact of alterations of the tRNA pool on ribosomal protein synthesis and co-translational folding, interacting with differences in codon usage, may have profound impact on the proteome throughout life. Indeed, proliferation-enriched and differentiation-enriched tRNAs preferentially have anticodons that are enriched to be represented respectively among cell-autonomous vs. intercellular communication genes, suggesting exquisite coordination between transcriptional and translational programs (217). Interestingly, tRNA-Leu overexpression can enhance phosphorylation of S6-kinase under amino acids starvation condition independent of mTOR signaling (218). This observation is consistent with the notion that tRNAs may also play more general regulatory functions.

Recent evidence has revealed the existence of a new class of small non-coding regulatory RNAs derived from tRNAs, known as tRFs (i.e. tRNA-derived fragments) (219). Although the biological roles of tRFs are still poorly understood, they have been suggested to play roles in regulating cell proliferation, gene expression and RNA processing, priming viral reverse transcriptases, and modulating the DNA damage response, tumor suppression, and neurodegeneration (219). For instance, inhibition of a tRF species derived from the 3' half of tRNA-Leu (CAG) can induce apoptosis and enhance the translation of two ribosomal protein (RPS28 and RPS15) (220).

The expression of tRNA genes is under the control of a specialized polymerase, RNA polymerase III (RNA Pol III) (221). Transcription of specific tRNA genes is thus likely to be influenced by remodeling of the chromatin landscape, notably during aging (1), which may disrupt the homeostasis of tRNA gene pools. Although RNA Pol III genes are generally thought of as 'housekeeping genes', recent evidence suggests that RNA Pol III target selection must be regulated at least in part (reviewed in (222)). Indeed, while a large majority of RNA Pol III target genes are shared across cell types and tissues, private targets exist and could be involved in tissue- or contextspecific responses (223). Interestingly, a recent study has shown that a reduction in RNA Pol III levels is associated to increased longevity downstream of TOR activity in yeast, worms and flies (224), supporting the idea that RNA Pol III (and its targets, including tRNA genes) may be a crucial mediator of the nutrient-signaling longevity pathway.

A systematic assessment of tRNA pools, derived tRFs, as well as RNA Pol III targets with mammalian aging will be crucial to understand the role of these phenomena on health and lifespan.

\section{GENERAL DISCUSSION AND IMPLICATIONS}

This review has painted a broad picture of the current knowledge in various aspects of transcriptional regulation in aging and longevity models. Understanding gene regulation and misregulation with aging will be of great use in order to help mitigate or reverse aging-related functional decline.

In addition to humans, sex differences in lifespan have been observed across taxa (10), and mammalian females across species are also generally longer-lived than males, including pilot whales, lions, red deer, prairie dogs, monkeys and apes (10). In most reported cases, female laboratory rats live longer than males (10). Although the existence of a similar female advantage for lifespan in laboratory mice is still debated (10), in standardized husbandry conditions developed for the NIA Interventions Testing Program (ITP), female individuals consistently outlive males at 3 independent sites (10), suggesting that the human female advantage may be recapitulated in laboratory mice in controlled conditions. Many health parameters differ between male and female mice with aging (225). Several reports have indicated that adult stem cell populations (i.e. HSCs, NSCs, MuSCs) show increased self-renewal and regenerative capacity in females compared to males (226). Moreover, females exhibit increased abilities for wound healing and liver regeneration (226). Surprisingly, interventions that successfully extend the health- and lifespan of laboratory mice often do so in a sex-dimorphic manner (10, $55,227)$. For instance, treatment with rapamycin preferentially extends female lifespan, whereas treatment with $17-\alpha$-estradiol only extends male lifespan (55). More surprisingly, genetic manipulations can also extend lifespan in a sex-dimorphic manner, leading to either greater lifespan extension in females vs. males (e.g. Igf1r haploinsufficiency), or to lifespan extension exclusively in males (e.g. Sirt6 overexpression) (10, 55). Though it has been proposed that differences in the bioavailability or metabolism of longevity-promoting compounds may be responsible for sex-dimorphic longevity effects, the existence of sex-dimorphic longevity effects upon genetic manipulations suggests that other underlying mechanisms are at work. Remarkably, thousands of genes can be regulated in a sex-dimorphic manner across a range of youthful healthy mouse and human somatic tissues (e.g. brain, liver, heart, muscle) (228-231). Genes expressed in a sex-dimorphic manner are located on autosomes as well as on sex chromosomes (228, 230-232), and many of these genes are not directly targeted by sex hormones (233). Functional enrichment analyses of sex-dimorphic gene regulation have identified differentially enriched pathways between male and female tissue transcriptomes, including immune response, oxidoreductase activity, and lipid metabolism (232). In addition, genes expressed in a sex-dimorphic manner in the human brain were proposed to act as mediators of stress susceptibility and depressive symptoms (234), consistent with the idea that sex-dimorphic expression can broadly impact human health and physiology. Studies in Drosophila have revealed that the sex-dimorphism in the expression of the mitochondrial Lon protease mediates sex- and age-specific adaptation to oxidative stress, and the sex-dimorphic expression of this protease may be conserved in mice (235). 
Interestingly, DR leads to a feminization of the gene expression profile of male mouse livers (i.e. rendering the gene expression profile of the organ more similar to that of females) (236). These observations raise the intriguing possibility that sex-dimorphic gene expression may play a key role in aging and response to longevity interventions. However, despite accumulating evidence of widespread sex-dimorphism in aging and lifespan across species as well as in mechanisms of gene regulation, few studies have investigated age-related sex-dimorphisms at the molecular level. Thus, systematically understanding the transcriptional underpinnings of sex differences in aging and longevity will be crucial to develop therapeutic strategies to slow down age-related functional decline and diseases which work in both males and females.

An important caveat to note for all studies of aging and longevity-associated transcriptional remodeling is that the penetrance of such transcriptional changes to cellular and organismal phenotypes may be limited (237). However, proteomics still has a lower sensitivity threshold and higher technical noise than RNA profiling. Thus, it will be important to systematically combine transcriptional mapping approaches to "proteome" and "translatome" mapping, notably through ribosome-profiling and mass spectrometry, to understand the relationship between mRNA levels and translated proteins (238).

Finally, transcriptional changes are the end-result of changes in upstream regulators, including chromatin remodeling $(1,2)$ and modulation of transcription factor activity (e.g. FOXOs, NRF2, etc.) $(239,240)$. The accumulating evidence showing that longevity-interventions can slow-down or reverse aspects of transcriptional aging suggests that aging can be modulated at the molecular level by environmental cues and genetic factors. Understanding the regulatory mechanisms leading to transcriptional defects with aging will be key in the design of therapeutic strategies to slow-down age-related decine, and delay the onset of age-related diseases.

\section{ACKNOWLEDGEMENTS}

The authors apologize to those whose work could not be included due to space constraints. J.B. is supported by NIA T32AG05237. B.A.B is supported by NIA R00AG049934 and the Hanson-Thorell family scholarship.

\section{CONFLICTS OF INTEREST}

The authors have no conflicting interests.

\section{REFERENCES}

1. Benayoun BA, Pollina EA and Brunet A (2015) Epigenetic regulation of ageing: linking environmental inputs to genomic stability. Nat Rev Mol Cell Biol 16, 593-610
2. Booth LN and Brunet A (2016) The Aging Epigenome. Mol Cell 62, 728-744

3. Pal S and Tyler JK (2016) Epigenetics and aging. Sci Adv 2, e1600584

4. Sen P, Shah PP, Nativio R and Berger SL (2016) Epigenetic Mechanisms of Longevity and Aging. Cell $166,822-839$

5. Kennedy BK, Berger SL, Brunet A et al (2014) Geroscience: linking aging to chronic disease. Cell 159, 709-713

6. Lopez-Otin C, Blasco MA, Partridge L, Serrano M and Kroemer G (2013) The hallmarks of aging. Cell 153, 1194-1217

7. Mortimer RK and Johnston JR (1959) Life span of individual yeast cells. Nature 183, 1751-1752

8. Hayflick L and Moorhead PS (1961) The serial cultivation of human diploid cell strains. Exp Cell Res 25, 585-621

9. Burtner CR and Kennedy BK (2010) Progeria syndromes and ageing: what is the connection? Nat Rev Mol Cell Biol 11, 567-578

10. Austad SN and Fischer KE (2016) Sex Differences in Lifespan. Cell Metab 23, 1022-1033

11. El Assar M, Angulo J and Rodriguez-Manas L (2013) Oxidative stress and vascular inflammation in aging. Free Radic Biol Med 65, 380-401

12. Ge W, Li D, Gao Y and Cao X (2015) The Roles of Lysosomes in Inflammation and Autoimmune Diseases. Int Rev Immunol 34, 415-431

13. Yamaoka M, Maeda N, Nakamura S et al (2013) Gene expression levels of S100 protein family in blood cells are associated with insulin resistance and inflammation (Peripheral blood S100 mRNAs and metabolic syndrome). Biochem Biophys Res Commun 433, 450-455

14. Mcllwain DR, Berger T and Mak TW (2013) Caspase functions in cell death and disease. Cold Spring Harb Perspect Biol 5, a008656

15. Gragnani A, Cezillo MV, da Silva ID, de Noronha SM, Correa-Noronha SA and Ferreira LM (2014) Gene expression profile of cytokines and receptors of inflammation from cultured keratinocytes of burned patients. Burns 40, 947-956

16. Cazander G, Jukema GN and Nibbering PH (2012) Complement activation and inhibition in wound healing. Clin Dev Immunol 2012, 534291

17. Franceschi C, Bonafè M, Valensin S (2000) Inflammaging: An Evolutionary Perspective on Immunosenescence. Ann N Y Acad Sci 908, 244-254

18. Franceschi $C$ and Campisi J (2014) Chronic inflammation (inflammaging) and its potential contribution to age-associated diseases. J Gerontol A Biol Sci Med Sci 69 Suppl 1, S4-9

19. Franceschi $C$, Garagnani $P$, Parini $P$, Giuliani $C$ and Santoro A (2018) Inflammaging: a new immunemetabolic viewpoint for age-related diseases. Nat Rev Endocrinol 14, 576-590

20. Munn LL (2017) Cancer and inflammation. Wiley Interdiscip Rev Syst Biol Med 9, e1370

21. Bellou V, Belbasis L, Tzoulaki I and Evangelou E (2018) Risk factors for type 2 diabetes mellitus: An exposure- 
wide umbrella review of meta-analyses. PLoS One 13, e0194127

22. Bobryshev YV, Ivanova EA, Chistiakov DA, Nikiforov NG and Orekhov AN (2016) Macrophages and Their Role in Atherosclerosis: Pathophysiology and Transcriptome Analysis. Biomed Res Int 2016, 9582430

23. Kietzmann T, Petry A, Shvetsova A, Gerhold JM and Gorlach A (2017) The epigenetic landscape related to reactive oxygen species formation in the cardiovascular system. Br J Pharmacol 174, 1533-1554

24. Lee CK, Weindruch R and Prolla TA (2000) Geneexpression profile of the ageing brain in mice. Nat Genet 25, 294-297

25. Sandovici I, Hammerle CM, Cooper WN et al (2016) Ageing is associated with molecular signatures of inflammation and type 2 diabetes in rat pancreatic islets. Diabetologia 59, 502-511

26. Yang J, Huang T, Petralia F et al (2015) Synchronized age-related gene expression changes across multiple tissues in human and the link to complex diseases. Sci Rep 5, 15145

27. Harris RA, Tindale L and Cumming RC (2014) Age-dependent metabolic dysregulation in cancer and Alzheimer's disease. Biogerontology 15, 559-577

28. Rodwell GE, Sonu R, Zahn JM et al (2004) A transcriptional profile of aging in the human kidney. PLoS Biol 2, e427

29. Kim IH, Xu J, Liu X et al (2016) Aging increases the susceptibility of hepatic inflammation, liver fibrosis and aging in response to high-fat diet in mice. Age (Dordr) 38, 291-302

30. Maquart FX and Monboisse JC (2014) Extracellular matrix and wound healing. Pathol Biol (Paris) 62, 91-95

31. Enomoto $\mathrm{H}$, Bando $\mathrm{Y}$, Nakamura $\mathrm{H}$, Nishiguchi $\mathrm{S}$ and Koga M (2015) Liver fibrosis markers of nonalcoholic steatohepatitis. World J Gastroenterol 21, 7427-7435

32. Kim JW, Ko SH, Cho JH et al (2008) Loss of beta-cells with fibrotic islet destruction in type 2 diabetes mellitus. Front Biosci 13, 6022-6033

33. Pibiri M, Sulas P, Leoni VP et al (2015) Global gene expression profile of normal and regenerating liver in young and old mice. Age (Dordr) 37, 9796

34. Lu L, Zhu C, Xia B and Yi C (2014) Oxidative demethylation of DNA and RNA mediated by non-heme iron-dependent dioxygenases. Chem Asian J 9, 2018-2029

35. Chandra R and Liddle RA (2013) Modulation of pancreatic exocrine and endocrine secretion. Curr Opin Gastroenterol 29, 517-522

36. Riera CE, Huising MO, Follett $P$ et al (2014) TRPV1 pain receptors regulate longevity and metabolism by neuropeptide signaling. Cell 157, 1023-1036

37. Ermolaeva M, Neri F, Ori A and Rudolph KL (2018) Cellular and epigenetic drivers of stem cell ageing. Nat Rev Mol Cell Biol 19, 594-610

38. Leeman DS, Hebestreit K, Ruetz T et al (2018) Lysosome activation clears aggregates and enhances quiescent neural stem cell activation during aging. Science 359, 1277-1283

39. Lupo G, Nisi PS, Esteve P et al (2018) Molecular profiling of aged neural progenitors identifies Dbx2 as a candidate regulator of age-associated neurogenic decline. Aging Cell 17, e12745

40. Liu L, Cheung TH, Charville GW et al (2013) Chromatin modifications as determinants of muscle stem cell quiescence and chronological aging. Cell Rep 4, 189-204

41. Price FD, von Maltzahn J, Bentzinger CF et al (2014) Inhibition of JAK-STAT signaling stimulates adult satellite cell function. Nat Med 20, 1174-1181

42. Chambers SM, Shaw CA, Gatza C, Fisk CJ, Donehower LA and Goodell MA (2007) Aging hematopoietic stem cells decline in function and exhibit epigenetic dysregulation. PLoS Biol 5, e201

43. Sun D, Luo $M$, Jeong $M$ et al (2014) Epigenomic profiling of young and aged HSCs reveals concerted changes during aging that reinforce self-renewal. Cell Stem Cell 14, 673-688

44. Kowalczyk MS, Tirosh I, Heckl D et al (2015) Single-cell RNA-seq reveals changes in cell cycle and differentiation programs upon aging of hematopoietic stem cells. Genome Res 25, 1860-1872

45. Kizil C, Kyritsis N and Brand M (2015) Effects of inflammation on stem cells: together they strive? EMBO Rep 16, 416-426

46. Newman AM, Liu CL, Green MR et al (2015) Robust enumeration of cell subsets from tissue expression profiles. Nat Methods 12, 453-457

47. Macosko EZ, Basu A, Satija R et al (2015) Highly Parallel Genome-wide Expression Profiling of Individual Cells Using Nanoliter Droplets. Cell 161, 1202-1214

48. Deng Q, Ramskold D, Reinius B and Sandberg R (2014) Single-cell RNA-seq reveals dynamic, random monoallelic gene expression in mammalian cells. Science 343, 193-196

49. Arda HE, Li L, Tsai J et al (2016) Age-Dependent Pancreatic Gene Regulation Reveals Mechanisms Governing Human beta Cell Function. Cell Metab 23, 909-920

50. Enge M, Arda HE, Mignardi $M$ et al (2017) Single-Cell Analysis of Human Pancreas Reveals Transcriptional Signatures of Aging and Somatic Mutation Patterns. Cell $171,321-330$ e 314

51. Islam S, Zeisel A, Joost S et al (2014) Quantitative single-cell RNA-seq with unique molecular identifiers. Nat Methods 11, 163-166

52. Wang T, Tsui B, Kreisberg JF et al (2017) Epigenetic aging signatures in mice livers are slowed by dwarfism, calorie restriction and rapamycin treatment. Genome Biol 18, 57

53. Cole JJ, Robertson NA, Rather MI et al (2017) Diverse interventions that extend mouse lifespan suppress shared age-associated epigenetic changes at critical gene regulatory regions. Genome Biol 18, 58

54. Koubova J and Guarente L (2003) How does calorie restriciton work? Genes Dev 17, 313-321

55. Fontana $L$ and Partridge $L$ (2015) Promoting health and longevity through diet: from model organisms to humans. Cell 161, 106-118

56. Katewa SD and Kapahi P (2010) Dietary restriction and aging, 2009. Aging Cell 9, 105-112

57. Li Y, Daniel M and Tollefsbol TO (2011) Epigenetic 
regulation of caloric restriction in aging. $\mathrm{BMC}$ Med 9, 98

58. Solon-Biet SM, MCMahon AC, Ballard JW et al (2014) The ratio of macronutrients, not caloric intake, dictates cardiometabolic health, aging, and longevity in ad libitum-fed mice. Cell Metab 19, 418-430

59. Grandison RC, Piper MD and Partridge L (2009) Amino-acid imbalance explains extension of lifespan by dietary restriction in Drosophila. Nature 462, 1061-1064

60. Ables GP, Brown-Borg HM, Buffenstein R et al (2014) The first international mini-symposium on methionine restriction and lifespan. Front Genet 5, 122

61. Nakagawa S, Lagisz M, Hector KL and Spencer HG (2012) Comparative and meta-analytic insights into life extension via dietary restriction. Aging Cell 11, 401-409

62. Pamplona R and Barja G (2006) Mitochondrial oxidative stress, aging and caloric restriction: the protein and methionine connection. Biochim Biophys Acta 1757, 496-508

63. Miller RA, Buehner G, Chang Y, Harper JM, Sigler R and Smith-Wheelock M (2005) Methionine-deficient diet extends mouse lifespan, slows immune and lens aging, alters glucose, T4, IGF-I and insulin levels, and increases hepatocyte MIF levels and stress resistance. Aging cell 4, 119-125

64. Richardson BC (2002) Role of DNA methylation in the regulation of cell function: autoimmunity, aging and cancer. J Nutr 132, 2401S-2405S

65. Bartke A and Brown-Borg H (2004) Life extension in the dwarf mouse. Curr Top Dev Biol 63, 189-225

66. Armstrong $\mathrm{VL}$, Rakoczy S, Rojanathammanee $\mathrm{L}$ and Brown-Borg HM (2014) Expression of DNA methyltransferases is influenced by growth hormone in the long-living Ames dwarf mouse in vivo and in vitro. J Gerontol A Biol Sci Med Sci 69, 923-933

67. Victoria B, Dhahbi JM, Nunez Lopez YO et al (2015) Circulating microRNA signature of genotype-by-age interactions in the long-lived Ames dwarf mouse. Aging Cell 14, 1055-1066

68. Bates DJ, Li N, Liang R et al (2010) MicroRNA regulation in Ames dwarf mouse liver may contribute to delayed aging. Aging Cell 9, 1-18

69. Aliper A, Jellen L, Cortese F et al (2017) Towards natural mimetics of metformin and rapamycin. Aging (Albany NY) 9, 2245-2268

70. Roth GS and Ingram DK (2016) Manipulation of health span and function by dietary caloric restriction mimetics. Ann N Y Acad Sci 1363, 5-10

71. Hall MN (2008) mTOR-what does it do? Transplant Proc 40, S5-8

72. Wilkinson JE, Burmeister L, Brooks SV et al (2012) Rapamycin slows aging in mice. Aging cell 11, 675-682

73. El-Mir MY, Nogueira V, Fontaine E, Averet N, Rigoulet $M$ and Leverve X (2000) Dimethylbiguanide inhibits cell respiration via an indirect effect targeted on the respiratory chain complex I. J Biol Chem 275, 223-228

74. Leff T (2003) AMP-activated protein kinase regulates gene expression by direct phosphorylation of nuclear proteins. Biochem Soc Trans 31, 224-227

75. Vinuela A, Snoek LB, Riksen JA and Kammenga JE (2010) Genome-wide gene expression regulation as a function of genotype and age in C. elegans. Genome Res 20, 929-937

76. Southworth LK, Owen AB and Kim SK (2009) Aging mice show a decreasing correlation of gene expression within genetic modules. PLoS Genet 5, e1000776

77. Wang ET, Sandberg R, Luo S et al (2008) Alternative isoform regulation in human tissue transcriptomes. Nature 456, 470-476

78. Bahar R, Hartmann $\mathrm{CH}$, Rodriguez KA et al (2006) Increased cell-to-cell variation in gene expression in ageing mouse heart. Nature 441, 1011-1014

79. Warren LA, Rossi DJ, Schiebinger GR, Weissman IL, Kim SK and Quake SR (2007) Transcriptional instability is not a universal attribute of aging. Aging cell 6, 775-782

80. Martinez-Jimenez CP, Eling N, Chen HC et al (2017) Aging increases cell-to-cell transcriptional variability upon immune stimulation. Science 355, 1433-1436

81. Dvinge $\mathrm{H}$ (2018) Regulation of alternative mRNA splicing: old players and new perspectives. FEBS Lett 592, 2987-3006

82. Pan Q, Shai O, Lee LJ, Frey BJ and Blencowe BJ (2008) Deep surveying of alternative splicing complexity in the human transcriptome by high-throughput sequencing. Nat Genet 40, 1413-1415

83. Deschenes M and Chabot B (2017) The emerging role of alternative splicing in senescence and aging. Aging Cell $16,918-933$

84. Raj T, Li Yl, Wong G et al (2018) Integrative transcriptome analyses of the aging brain implicate altered splicing in Alzheimer's disease susceptibility. Nat Genet 50, 15841592

85. Harries LW, Hernandez D, Henley W et al (2011) Human aging is characterized by focused changes in gene expression and deregulation of alternative splicing. Aging Cell 10, 868-878

86. Stilling RM, Benito E, Gertig M et al (2014) Deregulation of gene expression and alternative splicing affects distinct cellular pathways in the aging hippocampus. Front Cell Neurosci 8, 373

87. Tollervey JR, Wang Z, Hortobagyi T et al (2011) Analysis of alternative splicing associated with aging and neurodegeneration in the human brain. Genome Res 21, 1572-1582

88. Mazin P, Xiong J, Liu X, Yan Z et al (2013) Widespread splicing changes in human brain development and aging. Mol Syst Biol 9, 633

89. Rhoads TW, Burhans MS, Chen VB et al (2018) Caloric Restriction Engages Hepatic RNA Processing Mechanisms in Rhesus Monkeys. Cell Metab 27, 677-688.e675

90. Lee BP, Pilling LC, Emond F et al (2016) Changes in the expression of splicing factor transcripts and variations in alternative splicing are associated with lifespan in mice and humans. Aging Cell 15, 903-913

91. Heintz C, Doktor TK, Lanjuin A et al (2017) Splicing factor 1 modulates dietary restriction and TORC1 pathway longevity in C. elegans. Nature 541, 102-106

92. Goff LA and Rinn JL (2015) Linking RNA biology to IncRNAs. Genome Res 25, 1456-1465

93. Ruiz-Orera J, Messeguer X, Subirana JA and Alba MM (2014) Long non-coding RNAs as a source of new 
peptides. Elife 3, e03523

94. Choi SW, Kim HW and Nam JW (2018) The small peptide world in long noncoding RNAs. Brief Bioinform, bby055-bby055

95. Smith-Vikos T and Slack FJ (2012) MicroRNAs and their roles in aging. J Cell Sci 125, 7-17

96. Hofmann P, Sommer J, Theodorou K et al (2018) Long non-coding RNA $\mathrm{H} 19$ regulates endothelial cell aging via inhibition of Stat3 signaling. Cardiovasc Res 115, 230-242

97. Venkatraman A, He XC, Thorvaldsen JL et al (2013) Maternal imprinting at the H19-Igf2 locus maintains adult haematopoietic stem cell quiescence. Nature 500, 345-349

98. Yo K and Runger TM (2018) The long non-coding RNA FLJ46906 binds to the transcription factors NF-kappaB and AP-1 and regulates expression of aging-associated genes. Aging (Albany NY) 10, 2037-2050

99. Sanger HL, Klotz G, Riesner D, Gross HJ and Kleinschmidt AK (1976) Viroids are single-stranded covalently closed circular RNA molecules existing as highly base-paired rod-like structures. Proc Natl Acad Sci U S A 73, 3852-3856

100. Hsu MT and Coca-Prados M (1979) Electron microscopic evidence for the circular form of RNA in the cytoplasm of eukaryotic cells. Nature 280, 339-340

101. Salzman J, Gawad C, Wang PL, Lacayo N and Brown PO (2012) Circular RNAs are the predominant transcript isoform from hundreds of human genes in diverse cell types. PLoS One 7, e30733

102. Jeck WR, Sorrentino JA, Wang K et al (2013) Circular RNAs are abundant, conserved, and associated with ALU repeats. RNA 19, 141-157

103. Salzman J, Chen RE, Olsen MN, Wang PL and Brown PO (2013) Cell-type specific features of circular RNA expression. PLoS Genet 9, e1003777

104. Westholm JO, Miura P, Olson S et al (2014) Genome-wide analysis of drosophila circular RNAs reveals their structural and sequence properties and age-dependent neural accumulation. Cell Rep 9, 1966-1980

105. Cortes-Lopez M, Gruner MR, Cooper DA et al (2018) Global accumulation of circRNAs during aging in Caenorhabditis elegans. BMC Genomics 19, 8

106. Lu C, Sun X, Li N et al (2018) CircRNAs in the tree shrew (Tupaia belangeri) brain during postnatal development and aging. Aging (Albany NY) 10, 833-852

107. Nigro JM, Cho KR, Fearon ER et al (1991) Scrambled exons. Cell 64, 607-613

108. Hansen TB, Jensen TI, Clausen BH et al (2013) Natural RNA circles function as efficient microRNA sponges. Nature 495, 384-388

109. Hansen TB, Wiklund ED, Bramsen JB et al (2011) miRNA-dependent gene silencing involving Ago2-mediated cleavage of a circular antisense RNA. EMBO J 30, 4414-4422

110. Ashwal-Fluss R, Meyer M, Pamudurti NR et al (2014) circRNA biogenesis competes with pre-mRNA splicing. Mol Cell 56, 55-66

111. Chen CY and Sarnow P (1995) Initiation of protein synthesis by the eukaryotic translational apparatus on circular RNAs. Science 268, 415-417

112. Wang $Y$ and Wang $Z$ (2015) Efficient backsplicing produces translatable circular mRNAs. RNA 21, 172-179

113. Legnini I, Di Timoteo G, Rossi $F$ et al (2017) Circ-ZNF609 Is a Circular RNA that Can Be Translated and Functions in Myogenesis. Mol Cell 66, 22-37 e29

114. Rybak-Wolf A, Stottmeister C, Glazar P et al (2015) Circular RNAs in the Mammalian Brain Are Highly Abundant, Conserved, and Dynamically Expressed. Mol Cell 58, 870-885

115. Gruner H, Cortes-Lopez M, Cooper DA, Bauer M and Miura $P$ (2016) CircRNA accumulation in the aging mouse brain. Sci Rep 6, 38907

116. Chen K, Hu Z, Xia Z, Zhao D, Li W and Tyler JK (2015) The Overlooked Fact: Fundamental Need for Spike-In Control for Virtually All Genome-Wide Analyses. Mol Cell Biol 36, 662-667

117. Panda AC, Grammatikakis I, Kim KM et al (2017) Identification of senescence-associated circular RNAs (SAC-RNAs) reveals senescence suppressor CircPVT1. Nucleic Acids Res 45, 4021-4035

118. Dimri GP, Lee X, Basile G et al (1995) A biomarker that identifies senescent human cells in culture and in aging skin in vivo. Proc Natl Acad Sci U S A 92, 9363-9367

119. Baker DJ, Wijshake T, Tchkonia T et al (2011) Clearance of p16Ink4a-positive senescent cells delays ageingassociated disorders. Nature 479, 232-236

120. Piwecka M, Glazar P, Hernandez-Miranda LR et al (2017) Loss of a mammalian circular RNA locus causes miRNA deregulation and affects brain function. Science 357, eaam8526

121. Vijg J and Suh Y (2013) Genome instability and aging. Annu Rev Physiol 75, 645-668

122. McClintock B (1953) Induction of Instability at Selected Loci in Maize. Genetics 38, 579-599

123. Biémont C and Vieira C (2006) Junk DNA as an evolutionary force. Nature 443, 521

124. Sotero-Caio CG, Platt RN 2nd, Suh A and Ray DA (2017) Evolution and Diversity of Transposable Elements in Vertebrate Genomes. Genome Biol Evol 9, 161-177

125. Levin HL and Moran JV (2011) Dynamic interactions between transposable elements and their hosts. Nat Rev Genet 12, 615-627

126. Rebollo R, Romanish MT and Mager DL (2012) Transposable elements: an abundant and natural source of regulatory sequences for host genes. Annu Rev Genet 46, 21-42

127. Kidwell MG (2002) Transposable elements and the evolution of genome size in eukaryotes. Genetica 115, 49-63

128. Kidwell MG and Lisch D (1997) Transposable elements as sources of variation in animals and plants. Proc Nat Acad Sci U S A 94, 7704-7711

129. Treangen TJ and Salzberg SL (2011) Repetitive DNA and next-generation sequencing: computational challenges and solutions. Nat Rev Genet 13, 36-46

130. Bao W, Kojima KK and Kohany O (2015) Repbase Update, a database of repetitive elements in eukaryotic genomes. Mobile DNA 6, 11 
131. Rhoads A and Au KF (2015) PacBio Sequencing and Its Applications. Genomics Proteomics Bioinformatics 13, 278-289

132. Goodwin S, Gurtowski J, Ethe-Sayers S, Deshpande P, Schatz MC and McCombie WR (2015) Oxford Nanopore sequencing, hybrid error correction, and de novo assembly of a eukaryotic genome. Genome Res 25, 1750-1756

133. Bao J, Chen M, Zhong Z et al (2017) PacBio Sequencing Reveals Transposable Elements as a Key Contributor to Genomic Plasticity and Virulence Variation in Magnaporthe oryzae. Mol Plant 10, 1465-1468

134. Debladis E, Llauro C, Carpentier MC, Mirouze M and Panaud O (2017) Detection of active transposable elements in Arabidopsis thaliana using Oxford Nanopore Sequencing technology. BMC Genomics 18, 537

135. Kim Y, Nam HG and Valenzano DR (2016) The short-lived African turquoise killifish: an emerging experimental model for ageing. Dis Model Mech 9, 115129

136. Bessereau JL (2006) Transposons in C. elegans, WormBook, ed. The C. elegans Research Community, WormBook, doi/10.1895/wormbook.1.70.1, http://www. wormbook.org.

137. Quesneville H, Bergman CM, Andrieu O et al (2005) Combined evidence annotation of transposable elements in genome sequences. PLoS Comput Biol 1, 166-175

138. Loreto ELS and Pereira CM (2017) Somatizing the transposons action. Mobile Genetic Elements 7, 1-9

139. Lander ES, Linton LM, Birren B et al (2001) Initial sequencing and analysis of the human genome. Nature 409, 860-921

140. Lu S, Niu Z, Chen $Y$ et al (2018) Repetitive Element DNA Methylation is Associated with Menopausal Age. Aging Dis 9, 435-443

141. Yu Q, Carbone CJ, Katlinskaya YV et al (2015) Type I Interferon Controls Propagation of Long Interspersed Element-1. J Biol Chem 290, 10191- 10199

142. Valenzano DR, Benayoun BA, Singh PP et al (2015) The African Turquoise Killifish Genome Provides Insights into Evolution and Genetic Architecture of Lifespan. Cell $163,1539-1554$

143. Harel I, Benayoun BA, Machado B et al (2015) A platform for rapid exploration of aging and diseases in a naturally short-lived vertebrate. Cell 160, 1013-1026

144. Reichenbacher B and Reichard M (2014) Otoliths of five extant species of the annual killifish Nothobranchius from the East African savannah. PLoS One 9, e112459

145. Valdesalici S and Cellerino A (2003) Extremely short lifespan in the annual fish Nothobranchius furzeri. Proc Biol Sci 270 Suppl 2, S189-191

146. Kirschner J, Weber D, Neuschl C et al (2012) Mapping of quantitative trait loci controlling lifespan in the short-lived fish Nothobranchius furzeri-a new vertebrate model for age research. Aging Cell 11, 252-261

147. Valenzano DR, Kirschner J, Kamber RA et al (2009) Mapping loci associated with tail color and sex determination in the short-lived fish Nothobranchius furzeri. Genetics 183, 1385-1395

148. Terzibasi E, Valenzano DR, Benedetti M et al (2008)
Large differences in aging phenotype between strains of the short-lived annual fish Nothobranchius furzeri. PLoS One 3, e3866

149. Reichwald K, Petzold A, Koch P et al (2015) Insights into Sex Chromosome Evolution and Aging from the Genome of a Short-Lived Fish. Cell 163, 1527-1538

150. Di Cicco E, Tozzini ET, Rossi G and Cellerino A (2011) The short-lived annual fish Nothobranchius furzeri shows a typical teleost aging process reinforced by high incidence of age-dependent neoplasias. Exp Gerontol 46, 249-256

151. Terzibasi E, Valenzano DR and Cellerino A (2007) The short-lived fish Nothobranchius furzeri as a new model system for aging studies. Exp Gerontol 42, 81-89

152. Terzibasi E, Lefrancois C, Domenici P, Hartmann N, Graf $M$ and Cellerino A (2009) Effects of dietary restriction on mortality and age-related phenotypes in the short-lived fish Nothobranchius furzeri. Aging cell 8, 88-99

153. von Figura G, Wagner $M$, Nalapareddy K et al (2011) Regeneration of the exocrine pancreas is delayed in telomere-dysfunctional mice. PLoS One 6, e17122

154. Reichwald K, Lauber C, Nanda I et al (2009) High tandem repeat content in the genome of the short-lived annual fish Nothobranchius furzeri: a new vertebrate model for aging research. Genome Biol 10, R16

155. Yang F and Wang PJ (2016) Multiple LINEs of retrotransposon silencing mechanisms in the mammalian germline. Semin Cell Dev Biol 59, 118-125

156. Wood JG, Jones BC, Jiang N et al (2016) Chromatinmodifying genetic interventions suppress age-associated transposable element activation and extend life span in Drosophila. Proc Natl Acad Sci U S A 113, 11277-11282

157. Dang W, Steffen KK, Perry R et al (2009) Histone H4 lysine 16 acetylation regulates cellular lifespan. Nature $459,802-807$

158. Jiang N, Du G, Tobias E et al (2013) Dietary and genetic effects on age-related loss of gene silencing reveal epigenetic plasticity of chromatin repression during aging. Aging 5, 813-824

159. Rosenberg MI and Parkhurst SM (2002) Drosophila Sir2 Is Required for Heterochromatic Silencing and by Euchromatic Hairy/E(Spl) bHLH Repressors in Segmentation and Sex Determination. Cell 109, 447-458

160. Schotta G, Ebert A, Krauss V et al (2002) Central role of Drosophila SU(VAR)3-9 in histone H3-K9 methylation and heterochromatic gene silencing. EMBO J 21, 11211131

161. De Cecco M, Criscione SW, Peterson AL, Neretti N, Sedivy JM and Kreiling JA (2013) Transposable elements become active and mobile in the genomes of aging mammalian somatic tissues. Aging (Albany NY) 5, 867-883

162. Tsurumi A and Li WX (2012) Global heterochromatin loss: a unifying theory of aging? Epigenetics 7, 680-688

163. Sturm Á, Ivics Z and Vellai T (2015) The mechanism of ageing: primary role of transposable elements in genome disintegration. Cellular and Molecular Life Sciences 72, 1839-1847

164. Wood J and Helfand S (2013) Chromatin structure and 
transposable elements in organismal aging. Front Genet 4, Article 274

165. Liu N, Lee $\mathrm{CH}$, Swigut T et al (2017) Selective silencing of euchromatic L1s revealed by genome-wide screens for L1 regulators. Nature 553, 228

166. Stetson DB and Medzhitov R (2006) Type I Interferons in Host Defense. Immunity 25, 373-381

167. Cuellar TL, Herzner A-M, Zhang $X$ et al (2017) -Silencing of retrotransposons by SETDB1 inhibits the interferon response in acute myeloid leukemia-. J Cell Biol 216, 3535-3549

168. Tan MH, Li Q, Shanmugam R et al (2017) Dynamic landscape and regulation of RNA editing in mammals. Nature 550, 249-254

169. Li W, Prazak L, Chatterjee $N$ et al (2013) Activation of transposable elements during aging and neuronal decline in Drosophila. Nat Neurosci 16, 529-531

170. Ross RJ, Weiner MM and Lin H (2014) PIWI proteins and PIWI-interacting RNAs in the soma. Nature 505, 353-359

171. Perrat PN, DasGupta S, Wang J et al (2013) Transposition-Driven Genomic Heterogeneity in the Drosophila Brain. Science 340, 91-95

172. Teixeira FK, Okuniewska M, Malone CD, Coux R-X, Rio DC and Lehmann R (2017) piRNA-mediated regulation of transposon alternative splicing in the soma and germ line. Nature 552, 268

173. Martinez G (2018) tRNA-derived small RNAs: New players in genome protection against retrotransposons. RNA Biol 15, 170-175

174. Green CD, Huang Y, Dou X, Yang L, Liu Y and Han J-D J (2017) Impact of Dietary Interventions on Noncoding RNA Networks and mRNAs Encoding Chromatin-Related Factors. Cell Rep 18, 2957-2968

175. Percharde $M$, Lin C-J, Yin $Y$ et al (2018) A LINE1Nucleolin Partnership Regulates Early Development and ESC Identity. Cell 174, 391-405.e319

176. Doolittle WF and Sapienza C (1980) Selfish genes, the phenotype paradigm and genome evolution. Nature 284, 601-603

177. Dupressoir A, Lavialle C and Heidmann T (2012) From ancestral infectious retroviruses to bona fide cellular genes: role of the captured syncytins in placentation. Placenta 33, 663-671

178. Kassiotis G and Stoye JP (2016) Immune responses to endogenous retroelements: taking the bad with the good. Nature reviews. Immunology 16, 207-219

179. Hurst TP and Magiorkinis G (2015) Activation of the innate immune response by endogenous retroviruses. J Gen Virol 96, 1207-1218

180. Guo C, Jeong HH, Hsieh YC et al (2018) Tau Activates Transposable Elements in Alzheimer's Disease. Cell Rep 23, 2874-2880

181. Mackenzie IR and Rademakers R (2008) The role of transactive response DNA-binding protein-43 in amyotrophic lateral sclerosis and frontotemporal dementia. Curr Opin Neurol 21, 693-700

182. Li W, Jin Y, Prazak L, Hammell M and Dubnau J (2012) Transposable elements in TDP-43-mediated neurodegenerative disorders. PLoS One 7, e44099
183. Krug L, Chatterjee N, Borges-Monroy R et al (2017) Retrotransposon activation contributes to neurodegeneration in a Drosophila TDP-43 model of ALS. PLoS Genet 13, e1006635

184. Bartel DP (2004) MicroRNAs: genomics, biogenesis, mechanism, and function. Cell 116, 281-297

185. Friedman RC, Farh KK, Burge CB and Bartel DP (2009) Most mammalian mRNAs are conserved targets of microRNAs. Genome Res 19, 92-105

186. de Lencastre A, Pincus Z, Zhou K, Kato M, Lee SS and Slack FJ (2010) MicroRNAs both promote and antagonize longevity in C. elegans. Curr Biol 20, 21592168

187. Pincus Z, Smith-Vikos T and Slack FJ (2011) MicroRNA predictors of longevity in Caenorhabditis elegans. PLoS Genet 7, e1002306

188. Maes OC, An J, Sarojini H and Wang E (2008) Murine microRNAs implicated in liver functions and aging process. Mech Ageing Dev 129, 534-541

189. Mimura S, Iwama H, Kato K et al (2014) Profile of microRNAs associated with aging in rat liver. Int J Mol Med 34, 1065-1072

190. Kim JH, Lee BR, Choi ES et al (2017) Reverse Expression of Aging-Associated Molecules through Transfection of miRNAs to Aged Mice. Mol Ther Nucleic Acids 6, 106-115

191. Fenn AM, Smith KM, Lovett-Racke AE, Guerau-deArellano M, Whitacre CC and Godbout JP (2013) Increased micro-RNA 29b in the aged brain correlates with the reduction of insulin-like growth factor- 1 and fractalkine ligand. Neurobiol Aging 34, 2748-2758

192. Nolan K, Mitchem MR, Jimenez-Mateos EM, Henshall DC, Concannon CG and Prehn JH (2014) Increased expression of microRNA-29a in ALS mice: functional analysis of its inhibition. J Mol Neurosci 53, 231-241

193. Somel M, Guo S, Fu N et al (2010) MicroRNA, mRNA, and protein expression link development and aging in human and macaque brain. Genome Res 20, 1207-1218

194. Takahashi M, Eda A, Fukushima T and Hohjoh H (2012) Reduction of type IV collagen by upregulated miR-29 in normal elderly mouse and klotho-deficient, senescencemodel mouse. PLoS One 7, e48974

195. Ugalde AP, Ramsay AJ, de la Rosa J et al (2011) Aging and chronic DNA damage response activate a regulatory pathway involving miR-29 and p53. EMBO J 30, 2219-2232

196. Ripa R, Dolfi L, Terrigno $M$ et al (2017) MicroRNA miR-29 controls a compensatory response to limit neuronal iron accumulation during adult life and aging. BMC Biol 15, 9

197. Terzibasi Tozzini E, Savino A, Ripa R, Battistoni G, Baumgart M and Cellerino A (2014) Regulation of microRNA expression in the neuronal stem cell niches during aging of the short-lived annual fish Nothobranchius furzeri. Front Cell Neurosci 8, 51

198. Heid J, Cencioni C, Ripa R et al (2017) Age-dependent increase of oxidative stress regulates microRNA-29 family preserving cardiac health. Sci Rep 7, 16839

199. Boehm M and Slack F (2005) A developmental timing microRNA and its target regulate life span in C. elegans. 
Science 310, 1954-1957

200. Ha M and Kim VN (2014) Regulation of microRNA biogenesis. Nat Rev Mol Cell Biol 15, 509-524

201. Reis FC, Branquinho JL, Brandao BB et al (2016) Fat-specific Dicer deficiency accelerates aging and mitigates several effects of dietary restriction in mice. Aging (Albany NY) 8, 1201-1222

202. Takeda T and Tanabe H (2016) Lifespan and reproduction in brain-specific miR-29-knockdown mouse. Biochem Biophys Res Commun 471, 454-458

203. Lyu G, Guan Y, Zhang $C$ et al (2018) TGF- $\beta$ signaling alters H4K20me3 status via miR-29 and contributes to cellular senescence and cardiac aging. Nat Communs 9, 2560

204. Alvager T, Graham G, Hilleke R, Hutchison D and Westgard J (1989) On the information content of the genetic code. Biosystems 22, 189-196

205. Elf J, Nilsson D, Tenson T and Ehrenberg $M$ (2003) Selective charging of tRNA isoacceptors explains patterns of codon usage. Science 300, 1718-1722

206. Kimchi-Sarfaty C, Oh JM, Kim IW et al (2007) A "silent" polymorphism in the MDR1 gene changes substrate specificity. Science 315, 525-528

207. Zhao F, Yu CH and Liu Y (2017) Codon usage regulates protein structure and function by affecting translation elongation speed in Drosophila cells. Nucleic Acids Res 45, 8484-8492

208. Cohen E, Zafrir Z and Tuller T (2018) A code for transcription elongation speed. RNA Biol 15, 81-94

209. Plotkin JB and Kudla G (2011) Synonymous but not the same: the causes and consequences of codon bias. Nat Rev Genet 12, 32-42

210. Drummond DA and Wilke CO (2008) Mistranslationinduced protein misfolding as a dominant constraint on coding-sequence evolution. Cell 134, 341-352

211. Schieweck R, Popper B and Kiebler MA (2016) Co-Translational Folding: A Novel Modulator of Local Protein Expression in Mammalian Neurons? Trends Genet 32, 788-800

212. Gao FB, Richter JD and Cleveland DW (2017) Rethinking Unconventional Translation in Neurodegeneration. Cell $171,994-1000$

213. Goffena J, Lefcort F, Zhang Y et al (2018) Elongator and codon bias regulate protein levels in mammalian peripheral neurons. Nat Commun 9, 889

214. Strehler B, Hirsch G, Gusseck D, Johnson R and Bick M (1971) Codon-restriction theory by aging and development. J Theor Biol 33, 429-474

215. Dittmar KA, Goodenbour JM and Pan T (2006) Tissue-specific differences in human transfer RNA expression. PLoS Genet 2, e221

216. Sagi D, Rak R, Gingold H et al (2016) Tissue- and Time-Specific Expression of Otherwise Identical tRNA Genes. PLoS Genet 12, e1006264

217. Gingold H, Tehler D, Christoffersen NR et al (2014) A dual program for translation regulation in cellular proliferation and differentiation. Cell 158, 1281-1292

218. Kwon NH, Lee MR, Kong J et al (2017) Transfer-RNAmediated enhancement of ribosomal proteins S6 kinases signaling for cell proliferation. RNA Biol, 1-14
219. Kumar P, Kuscu C and Dutta A (2016) Biogenesis and Function of Transfer RNA-Related Fragments (tRFs). Trends Biochem Sci 41, 679-689

220. Kim HK, Fuchs G, Wang S et al (2017) A transfer-RNAderived small RNA regulates ribosome biogenesis. Nature 552, 57-62

221. Arimbasseri AG and Maraia RJ (2016) RNA Polymerase III Advances: Structural and tRNA Functional Views. Trends Biochem Sci 41, 546-559

222. Park JL, Lee YS, Kunkeaw N, Kim SY, Kim IH and Lee YS (2017) Epigenetic regulation of noncoding RNA transcription by mammalian RNA polymerase III. Epigenomics 9, 171-187

223. Oler AJ, Alla RK, Roberts DN et al (2010) Human RNA polymerase III transcriptomes and relationships to Pol II promoter chromatin and enhancer-binding factors. Nat Struct Mol Biol 17, 620-628

224. Filer D, Thompson MA, Takhaveev $V$ et al (2017) RNA polymerase III limits longevity downstream of TORC1. Nature 552, 263-267

225. Fischer KE, Hoffman JM, Sloane LB et al (2016) A cross-sectional study of male and female C57BL/6Nia mice suggests lifespan and healthspan are not necessarily correlated. Aging (Albany NY) 8, 2370-2391

226. Dulken B and Brunet A (2015) Stem Cell Aging and Sex: Are We Missing Something? Cell Stem Cell 16, 588-590

227. Harrison DE, Strong R, Allison DB et al (2014) Acarbose, 17-alpha-estradiol, and nordihydroguaiaretic acid extend mouse lifespan preferentially in males. Aging Cell 13, 273-282

228. Berchtold NC, Cribbs DH, Coleman PD et al (2008) Gene expression changes in the course of normal brain aging are sexually dimorphic. Proc Natl Acad Sci U S A 105, 15605-15610

229. Zhang JZ, Gao W, Yang HB, Zhang B, Zhu ZY and Xue YF (2006) Screening for genes essential for mouse embryonic stem cell self-renewal using a subtractive RNA interference library. Stem Cells 24, 2661-2668

230. Isensee J, Witt H, Pregla R, Hetzer R, Regitz-Zagrosek V and Noppinger PR (2008) Sexually dimorphic gene expression in the heart of mice and men. J Mol Med (Berl) 86, 61-74

231. Qureshi IA and Mehler MF (2010) Genetic and epigenetic underpinnings of sex differences in the brain and in neurological and psychiatric disease susceptibility. Prog Brain Res 186, 77-95

232. Yang X, Schadt EE, Wang $S$ et al (2006) Tissue-specific expression and regulation of sexually dimorphic genes in mice. Genome Res 16, 995-1004

233. Mayne BT, Bianco-Miotto T, Buckberry S et al (2016) Large Scale Gene Expression Meta-Analysis Reveals Tissue-Specific, Sex-Biased Gene Expression in Humans. Front Genet 7, 183

234. Labonte B, Engmann O, Purushothaman I et al (2017) Sex-specific transcriptional signatures in human depression. Nat Med 23, 1102-1111

235. Pomatto LC, Carney C, Shen B et al (2017) The Mitochondrial Lon Protease Is Required for Age-Specific and Sex-Specific Adaptation to Oxidative Stress. Curr Biol 27, 1-15 
236. Estep PW, 3rd Warner JB and Bulyk ML (2009) Short-term calorie restriction in male mice feminizes gene expression and alters key regulators of conserved aging regulatory pathways. PLoS One 4, e5242

237. Maier T, Guell M and Serrano L (2009) Correlation of mRNA and protein in complex biological samples. FEBS Lett 583, 3966-3973

238. Ori A, Toyama BH, Harris MS et al (2015) Integrated Transcriptome and Proteome Analyses Reveal Organ-Specific Proteome Deterioration in Old Rats. Cell Syst 1, 224-237

239. Martins R, Lithgow GJ and Link W (2016) Long live FOXO: unraveling the role of FOXO proteins in aging and longevity. Aging Cell 15, 196-207

240. Silva-Palacios A, Ostolga-Chavarria $M$, Zazueta $C$ and Konigsberg M (2018) Nrf2: Molecular and epigenetic regulation during aging. Ageing Res Rev 47, 31-40

241. Lee JS, Ward WO, Ren $\mathrm{H}$ et al (2012) Meta-analysis of gene expression in the mouse liver reveals biomarkers associated with inflammation increased early during aging. Mech Ageing Dev 133, 467-478

242. Bochkis IM, Przybylski D, Chen J and Regev A (2014) Changes in nucleosome occupancy associated with metabolic alterations in aged mammalian liver. Cell Rep 9, 996-1006

243. White RR, Milholland B, MacRae SL, Lin M, Zheng D and Vijg J (2015) Comprehensive transcriptional landscape of aging mouse liver. BMC Genomics 16, 899

244. Baumgart M, Priebe S, Groth M et al (2016) Longitudinal RNA-Seq Analysis of Vertebrate Aging Identifies Mitochondrial Complex I as a Small-Molecule-Sensitive Modifier of Lifespan. Cell Syst 2, 122-132

245. Bartling B, Niemann K, Pliquett RU, Treede H and Simm A (2018) Altered gene expression pattern indicates the differential regulation of the immune response system as an important factor in cardiac aging. Exp Gerontol [Epub ahead of print]

246. Avrahami D, Li C, Zhang J et al (2015) Aging-Dependent Demethylation of Regulatory Elements Correlates with Chromatin State and Improved beta Cell Function. Cell Metab 22, 619-632

247. Xin Y, Okamoto H, Kim J et al (2016) Single-Cell RNAseq Reveals That Pancreatic beta-Cells From Very Old Male Mice Have a Young Gene Signature. Endocrinology 157, 3431-3438

248. Baumgart M, Groth M, Priebe $S$ et al (2014) RNA-seq of the aging brain in the short-lived fish $\mathrm{N}$. furzeri conserved pathways and novel genes associated with neurogenesis. Aging Cell 13, 965-974

249. Liu L, Cheung TH, Charville GW et al (2013) Chromatin modifications as determinants of muscle stem cell quiescence and chronological aging. Cell reports 4, 189-204

250. Sun D, Luo $M$, Jeong $M$ et al (2014) Epigenomic profiling of young and aged HSCs reveals concerted changes during aging that reinforce self-renewal. Cell stem cell 14, 673-688

251. Gokarn R, Solon-Biet SM, Cogger VC et al (2018) Long-term Dietary Macronutrients and Hepatic Gene Expression in Aging Mice. J Gerontol A Biol Sci Med Sci
73, 1618-1625

252. Kawakami K, Nakamura A and Goto S (2012) Dietary restriction increases site-specific histone $\mathrm{H} 3$ acetylation in rat liver: possible modulation by sirtuins. Biochem Biophys Res Commun 418, 836-840

253. Zullo A, Simone E, Grimaldi M et al (2018) Effect of nutrient deprivation on the expression and the epigenetic signature of sirtuin genes. Nutr Metab Cardiovasc Dis 28, 418-424

254. Hadad N, Unnikrishnan A, Jackson JA et al (2018) Caloric restriction mitigates age-associated hippocampal differential CG and non-CG methylation. Neurobiol Aging 67, 53-66

255. Schafer MJ, Dolgalev I, Alldred MJ, Heguy A and Ginsberg SD (2015) Calorie Restriction Suppresses Age-Dependent Hippocampal Transcriptional Signatures. PLoS One 10, e0133923

256. Gong H, Qian H, Ertl R et al (2015) Histone modifications change with age, dietary restriction and rapamycin treatment in mouse brain. Oncotarget 6, 15882-15890

257. Swindell WR, List EO, Berryman DE and Kopchick JJ (2018) Transcriptional profiling identifies strain-specific effects of caloric restriction and opposite responses in human and mouse white adipose tissue. Aging (Albany NY) 10, 701-746

258. Deepa SS, Unnikrishnan A, Matyi S, Hadad N and Richardson A (2018) Necroptosis increases with age and is reduced by dietary restriction. Aging Cell, e12770

259. Martin-Montalvo A, Mercken EM, Mitchell SJ et al (2013) Metformin improves healthspan and lifespan in mice. Nat Commun 4, 2192

260. Chen H, Zheng X, Xiao D and Zheng $Y$ (2016) Age-associated de-repression of retrotransposons in the Drosophila fat body, its potential cause and consequence. Aging Cell 15, 542-552

261. De Cecco $M$, Criscione SW, Peterson AL, Neretti $N$, Sedivy JM and Kreiling JA (2013) Transposable elements become active and mobile in the genomes of aging mammalian somatic tissues. Aging (Albany NY) 5, 867-883

262. Hendrickson PG, Dorais JA, Grow EJ et al (2017) Conserved roles of mouse DUX and human DUX4 in activating cleavage-stage genes and MERVL/HERVL retrotransposons. Nat Genet 49, 925-934

263. Mita P, Wudzinska A, Sun X et al (2018) LINE-1 protein localization and functional dynamics during the cell cycle. Elife 7

264. Ang YS, Tsai SY, Lee DF et al (2011) Wdr5 mediates self-renewal and reprogramming via the embryonic stem cell core transcriptional network. Cell 145, 183-197

265. Wang J, Geesman GJ, Hostikka SL et al (2011) Inhibition of activated pericentromeric SINE/Alu repeat transcription in senescent human adult stem cells reinstates self-renewal. Cell Cycle 10, 3016-3030

266. Thomas CA, Tejwani L, Trujillo CA et al (2017) Modeling of TREX1-Dependent Autoimmune Disease using Human Stem Cells Highlights L1 Accumulation as a Source of Neuroinflammation. Cell Stem Cell 21, 319-331 e318 
267. Prudencio M, Gonzales PK, Cook CN et al (2017) Repetitive element transcripts are elevated in the brain of C9orf72 ALS/FTLD patients. Hum Mol Genet 26, 3421-3431

268. Sephton CF, Cenik C, Kucukural A et al (2011) Identification of neuronal RNA targets of TDP-43containing ribonucleoprotein complexes. J Biol Chem 286, 1204-1215

269. Polymenidou M, Lagier-Tourenne C, Hutt KR et al (2011) Long pre-mRNA depletion and RNA missplicing contribute to neuronal vulnerability from loss of TDP-43. Nat Neurosci 14, 459-468

270. Shan X, Chiang PM, Price DL and Wong PC (2010) Altered distributions of Gemini of coiled bodies and mitochondria in motor neurons of TDP-43 transgenic mice. Proc Natl Acad Sci U S A 107, 16325-16330

271. Rodić N, Sharma R, Sharma R et al (2014) Long Interspersed Element-1 Protein Expression Is a Hallmark of Many Human Cancers. Am J Pathol 184, 1280-1286 